\title{
Cartografia do pensamento político brasileiro: conceito, história, abordagens
}

A cartography of Brazilian political thought:

concept, history and approaches

Há vinte anos o campo de estudos do pensamento político brasileiro ( $\mathrm{PPB}$ ) vem crescendo exponencialmente na área de ciência política. Duas foram as teses de doutorado defendidas ao longo da década de 1980, número que subiu a doze na de 1990 e chegou a dezoito na de 2000. Prevê-se que se aproxime de trinta em 2020. Não é de hoje que se reclama um balanço do campo, capaz de fornecer uma ideia preliminar do que nele está acontecendo e permitir-lhe uma expansão mais rigorosa e autoconsciente. Desde que Maria Tereza Sadek publicou Análises do pensamento social e político brasileiro, em 1982, não se fez nada além de referências genéricas à natureza do campo e ao seu crescimento. É esta lacuna que ora se pretende preencher, oferecendo ao leitor um mapa conceitual, histórico e analítico da área temática do PPB, tal como ela hoje se encontra organizada. Na primeira seção do artigo, explicam-se as razões da indeterminação terminológica na designação do campo de estudos e indagam-se os significados possíveis do conceito de PPB, seja como objeto, seja como disciplina. Na segunda seção, considerado o PPB como objeto, sustenta-se que aquela expressão, no sentido lato, designa o conjunto de ideologias de que nossa cultura política é composta, vazadas em um estilo "periférico" dotado de certas características.

\footnotetext{
*É professor do Programa de Pós-Graduação em Ciência Política do Instituto de Estudos Sociais e Políticos da Universidade do Estado do Rio de Janeiro (lesp-Uerj) e do Programa de Pós-Graduação em Direito da Universidade Veiga de Almeida (UVA); é também pesquisador da Fundação Casa de Rui Barbosa (FCRB) e do Conselho Nacional de Desenvolvimento Científico e Tecnológico (CNPq). E-mail: clynch@iesp.uerj.br.
} 
Do ponto vista estrito, a expressão PPB se refere a um reduzido número de escritos que comporiam o cânone de "clássicos" expressivos de uma teoria e/ou da "velha" ciência política brasileira, praticada por juristas, sociólogos e economistas antes da especialização universitária. Definida a natureza do objeto e delineados os seus contornos, apresenta-se na terceira seção deste trabalho o balanço do PPB como disciplina universitária surgida na década de 1970. Historia-se o seu desenvolvimento, descrevem-se suas sucessivas e diferentes interpretações, seus pesquisadores mais notáveis e seus principais três grupos de pesquisa, aqui chamados mannheimiano, lukacsiano e gramsciano, em função de seus principais referenciais teóricos. O esforço inclui tabelas contendo as teses defendidas sob a rubrica de PPB na ciência política, relacionadas por título, nome, ano, orientador e instituição, assim como um gráfico descrevendo a variação do número de teses defendidas ao longo dos quinquênios. $\mathrm{O}$ artigo conclui com considerações críticas e sugestões de medidas para o fortalecimento do campo de estudos, estreitando suas relações com a teoria política.

Antes de passar ao artigo propriamente dito, dois esclarecimentos se impõem. Em primeiro lugar, a decisão de examinar o PPB "verticalmente" no âmbito de suas relações com a teoria política e da história do pensamento político, tal como compreendidas pela ciência política norte-americana e europeia, permitiu o oferecimento de um panorama "puro-sangue" do campo, que assegurou o rigor do empreendimento e manteve sua identidade disciplinar. Era o que convinha, aliás, a um balanço do campo realizado sob os auspícios da Associação Brasileira de Ciência Política (ABCP), como este de fato foi. Mas essa opção não foi feita sem sacrifícios. O maior deles foi ter de excluir da análise aqui empreendida os estudos análogos sobre o pensamento brasileiro realizados "horizontalmente" em outras áreas das ciências humanas. Mas achei que valia a pena correr o risco, a despeito das circunstâncias mais pragmáticas que suscitaram a elaboração deste trabalho. Primeiro, por já existirem alguns balanços do chamado "pensamento social brasileiro" no âmbito das ciências sociais. Em segundo lugar, as ciências humanas desenvolveram histórias disciplinares autônomas, marcadas por distintos pressupostos, interesses e métodos de trabalho. Não se faz aqui a apologia do insulamento, evidentemente: na casa do Senhor há muitas moradas. Para evitar os riscos do estreitamento de vistas e a esclerose intelectual, o estudioso do PPB deverá beber sempre que possível nas águas do pensamento social 
brasileiro, conhecendo as contribuições aportadas por antropólogos, como Lilia Schwarcz; economistas, como Ricardo Bielschowsky; filósofos, como Antônio Paim, Vicente Barreto e Eduardo Jardim; historiadores, como Arno Wehling, Lúcia Bastos, Marcello Basile e António Herculano; juristas, como Ricardo Fonseca, Samuel Barbosa e Aírton Seelaender; críticos literários, como Antonio Candido, Roberto Schwarz e Luiz Costa Lima; sociólogos, como Ângela Alonso, André Botelho, Edison Bariani, Élide Rugai, José Almino, Nísia Trindade, Ricardo Benzaquen, Robert Wegner e Sergio Miceli. Ainda assim, a produtividade do diálogo interdisciplinar do cientista político no campo do PPB dependerá de sua familiarização com os problemas e os métodos da teoria política e da história do pensamento político. As viagens são mais proveitosas quando se conhece bem o rincão natal.

O segundo esclarecimento diz respeito à eventual estranheza de não se encontrar aqui uma releitura aprofundada da famosa questão atinente às tradições ou linhagens do PPB. De fato, o artigo não se faz mais do que descrever em linhas gerais, na seção dedicada a historiar a disciplina, as classificações contidas nas interpretações de Wanderley Guilherme dos Santos, Bolívar Lamounier e Gildo Marçal Brandão. Para ser examinado a fundo, o assunto demandaria uma prévia análise da lógica e dos diferentes filtros de que aqueles intérpretes se serviram na formulação de suas classificações. Semelhante esforço exigiria, por sua vez, investigar a função exercida pelo conceito de cânone na história do pensamento político e o modo pelo qual os estudiosos dos países centrais elegeram categorias como idealismo e realismo para classificar, em tradições intelectuais, inventadas ou orgânicas, os chamados "clássicos da política". Compreender-se-iam então a lógica e as razões que motivaram aqueles intérpretes do $\mathrm{PPB}$ a adotarem os critérios que vieram de fato a empregar nas ditas classificações, compatíveis com suas particulares visões de mundo informadas, respectivamente, pelas tradições do nacionalismo, do liberalismo e do marxismo. Só então poderia, quem sabe, arriscar-me a uma classificação alternativa que, sem ilusões de neutralidade, mas adotando uma posição compreensiva, aproveitasse os elementos das demais para oferecer um panorama mais completo das nossas famílias intelectuais. Por fim, agradeço às sugestões e comentários formulados em diferentes momentos desta pesquisa por Wanderley Guilherme, Marcelo Jasmin, Bernardo Ricupero e Marcelo Sevaybricker, que foram fundamentais para o trabalho ora apresentado. 


\section{Razões de uma indeterminação terminológica}

O campo de estudos do PPB na ciência política ainda convive com diversas denominações: pensamento social brasileiro, pensamento político-social brasileiro, pensamento social e político brasileiro, etc. Variam também os nomes das linhas de pesquisa. Se, na Universidade do Estado do Rio de Janeiro (Uerj), ela se chama "pensamento político brasileiro", na Universidade de São Paulo (USP) ela se chama "história das ideias políticas no Brasil"; na Universidade Federal de Minas Gerais (UFMG), "pensamento político e social brasileiro"; na Universidade Federal Fluminense (UFF), "interpretações do Brasil”; etc. Quais as razões dessa aparente anomalia, quando as demais áreas temáticas da ciência política apresentam uma denominação uniforme?

Essa profusão terminológica parece relacionada, em primeiro lugar, ao modo de emergência do campo de estudos. A "velha" ciência política brasileira naturalmente desconhecia as fronteiras que depois, quando de sua institucionalização universitária, lhe seriam traçadas pela "nova”. Além disso, ao contrário do que ocorreu na sociologia, o advento da "nova" não rompeu com a agenda de pesquisas da "velha" (Lamounier, 1982). Dois dos principais responsáveis pela fundação da área de ciência política, Wanderley Guilherme dos Santos e Bolívar Lamounier, também se encarregaram da criação do campo de estudos do $\mathrm{PPB}^{1}$. Na verdade, eles já se dedicavam ao assunto antes de se irem para os Estados Unidos e se tornarem "cientistas políticos". Debruçaram-se sobre um acervo de obras que, recorrendo à sociologia, à economia, à história, não se encaixavam retrospectivamente na definição de ciência política que traziam de Stanford e da Universidade da Califórnia, restrita ao "sistema político" de David Easton - o que podia levá-los a eventualmente hesitarem sobre a designação do campo. Embora este nunca tenha sido o caso de Bolívar, Wanderley só delineou o político ao longo dos sucessivos artigos de sua pesquisa: o primeiro (1965) falava em "pensamento social”; o segundo (1967), em “imaginação político-social”; o terceiro (1970),

1 É verdade que essa história não combina com aquela outra, mais conhecida, segundo a qual os métodos empíricos e quantitativos emulados dos Estados Unidos seriam a marca distintiva da cientificidade na área e "que a política consistiria numa dimensão própria da realidade social, que não se subsume à estrutura socioeconômica" (Moreira, 2012, p. 85). Desenvolvida nos Estados Unidos para promover a democracia lá existente, a recepção da ciência política empírica no Brasil se deu sob o regime militar. Para criticar a tradição autoritária brasileira, era indispensável o recurso à teoria e ao pensamento brasileiro. O cientista político brasileiro das primeiras gerações incorporava certo etos cientificista, mas, ao mesmo tempo, fazia a crítica de uma "política apolítica" (Lessa, 2011). 
por fim, fixou-se em “imaginação política” (Lynch, 2013b). Além disso, tendo em vista o diminuto número de cientistas sociais em torno de 1980, em vez de criarem um grupo de trabalho à parte, os politólogos se juntaram aos sociólogos e aos antropólogos para criar junto à Associação Nacional de Pós-Graduação em Ciências Sociais (Anpocs) um único grupo de trabalho (GT) sob a denominação "Pensamento Social no Brasil" (Oliveira, 1995). Em suma: o fantasma do "social" rondava o nome do campo de estudos do PPB à época do seu surgimento, há quarenta anos, fosse pela estreiteza do "novo" conceito de ciência política no enquadramento das obras produzidas antes da institucionalização, fosse pela consagração, nos primórdios das ciências sociais, da designação geral datada da década de 1950.

A escalada de conflitos que estremeceram as relações entre cientistas políticos "teóricos" e "empíricos" na virada do século foi outro fator que prolongou em certos lugares a partícula "social" na designação do campo do PPB. Se, no curso do processo, alguns dos "empíricos" mais famosos, como Gláucio Soares, acusavam "teóricos” de consumirem recursos públicos em discussões pedantes que pouco ou nada contribuíam para a resolução das mazelas nacionais (Soares, 2005, p. 52), "teóricos" como Renato Lessa e Gildo Marçal Brandão questionaram a possibilidade de uma ciência purificada de normatividade e acusaram o caráter ideológico dos métodos veiculados pelos “empíricos" como neutros (Lessa, 1998; Brandão, 1998; Moreira, 2012). Potencializados pela luta por hegemonia dentro da Associação Brasileira de Ciência Política (ABCP), os conflitos chegaram ao ponto de reconhecer, em balanço da área realizado há dez anos, que "as duas principais formas de abordagem simplesmente não se comunicam entre si" (Amorim Neto e Santos, 2005, p. 102 e 107). No que nos interessa mais de perto, importa salientar que o exagero dos "empíricos" em restringirem o domínio da política àquele das instituições levou os "teóricos" mais combativos a reafirmarem seguidamente a dependência do político face ao social e do econômico. A atitude se refletiu pelo emprego, como sinônimas de PPB, de expressões como "pensamento social brasileiro", "pensamento social no Brasil", "pensamento político-social” e "pensamento político e social” (Brandão, 2007, p. 22-23). Os "teóricos" empenhados na luta não percebiam que, ao alardearem a necessidade de se acrescentar a partícula "social" à denominação do campo, involuntariamente chancelavam a definição restritiva de ciência política veiculada por seus adversários. Essa situação só começou a ser revertida 
com o arrefecimento dos ânimos entre "teóricos" e "empíricos"2 no âmbito da ABCP e a consolidação da expressão pensamento político brasileiro para designar a área temática a ela correspondente (2013).

Do ponto de vista do seu significado, o conceito de PPB designa um objeto e uma disciplina. Como objeto, ele pode ser entendido em um sentido amplo ou estrito. Em sentido amplo, o PPB se refere ao conjunto de escritos de natureza ideológica representativos da cultura política brasileira, marcados por um estilo periférico de reflexão. Emprego aqui o conceito de ideologia no sentido fraco de "conjunto de ideias e de valores respeitantes à ordem pública e tendo por função orientar os comportamentos políticos coletivos" (Stoppino, 1998, p. 585). No sentido estrito, a expressão PPB se refere a um círculo mais reduzido de obras que, dotadas de maior fôlego e sistematicidade, pretenderam descrever nossa realidade política com maior fidedignidade e como tal passaram a integrar uma espécie de cânone dos "clássicos" do PPB. Encara-se o PPB então como uma teoria política e/ou $a$ "velha" ciência política, elaborada antes da institucionalização universitária. Por essa última expressão, deve-se entender "qualquer estudo dos fenômenos e das estruturas políticas, conduzido sistematicamente e com rigor, apoiado num amplo e cuidadoso exame dos fatos expostos com argumentos racionais" (Bobbio, 1997, p. 164).

\section{O pensamento político brasileiro como objeto: sentido amplo}

A política repousa sobre o dado da pluralidade humana no contexto de uma comunidade composta de seres de múltiplas crenças e interesses. É por seu intermédio que indivíduos e grupos negociam, implantam e asseguram o cumprimento das diferentes demandas que formulam entre si ou face da coletividade. Por cultura política, entende-se aqui o conjunto de discursos ou práticas simbólicas por que tais demandas são efetuadas, conferindo identidades aos indivíduos e grupos, indicando-lhes os limites de suas comunidades e definindo as posições a partir das quais podem demandar. Uma cultura política é atravessada por discursos, práticas simbólicas ou ideologias

2 Se, por um lado, os "empíricos" asseguraram suas posições, o institucionalismo da escolha racional perdeu força à medida que "a agenda do seu programa de pesquisa amadureceu" e seus adeptos reabriram "a interlocução sistemática com a história e a cultura" (Araújo e Reis, 2005, p. 61). O conflito se ancorava em "divisões artificiais, baseadas mais em diferenças de estilos intelectuais e objetos de investigação, próprias de uma disciplina marcada pela pluralidade, que em divergências reais"(Amorim e Santos, 2015). 
orientadas por diferentes valores e/ou interpretações da realidade. Os fatos políticos precisam ser interpretados à luz dos valores, crenças, interesses e objetivos dos diversos segmentos de que a sociedade é composta. As ideologias ou discursos políticos são, portanto, conjuntos de "ideias, crenças, opiniões e valores que exibem um padrão recorrente; que possuem grupos significativos como seus portadores; competem pelo fornecimento e controle das políticas públicas, com o objetivo de justificar, contestar ou alterar os processos e arranjos políticos e sociais de uma comunidade política" (Freeden, 2003, p. 32). São metáforas, símbolos e temas prenhes de significados, que pretendem ordenar a realidade política por meio de determinadas narrativas sobre o passado, o presente e o futuro da comunidade. As ideologias apresentam três funções: servem de mapas para que indivíduos e grupos sociais se orientem meio à complexidade e à opacidade do mundo; são defendidas por grupos identificáveis que disputam a preferência daqueles que detém o poder; e almejam justificar, contestar e transformar os arranjos e processos sociais e políticos. Elas se adaptam às mudanças sociais, ao mesmo tempo que reivindicam uma tradição, composta de antecessores, verdadeiros ou inventados, na forma de mártires, doutrinários ou heróis. A expressão "pensamento político", por sua vez, é empregada aqui no sentido admitido na literatura internacional para designar um conjunto de autores ou obras pertencentes a uma determinada nacionalidade (Lynch, 2013a, p. 733). Entende-se neste caso que, sem pensamento político, a comunidade política não poderia ser organizada e tampouco existir. Por isso, toda comunidade organizada possui necessariamente alguma modalidade de pensamento político. O Brasil não pode ser uma exceção: existe um PPB tanto quanto um pensamento político argentino, paraguaio, estadunidense, francês, inglês, russo ou chinês. Cada um deles remete ao conjunto de ideologias e discursos que confirmam suas respectivas culturas políticas, apresentando entre si tanto semelhanças quanto especificidades ${ }^{3}$.

3 Curiosamente, houve um "intérprete" do PPB que negasse a existência do PPB: trata-se de Raimundo Faoro, na obra Existe um pensamento político brasileiro? Segundo o jurista gaúcho, a sociedade brasileira seguiria aprisionada em uma espécie de Antigo Regime disfarçado, em que prevaleceria uma cultura política ibérica, de traços pré-modernos. O propalado liberalismo brasileiro não seria "autêntico", porque inorgânico, estatista e conservador; ele seria manipulado pela classe dominante para fins de ornamentação e manutenção do status quo (Faoro, 1996, p. 67). Embora tenha sido útil no combate à herança autoritária do regime militar, esta é uma concepção de PPB academicamente inaceitável. Vários motivos levam à essa recusa. Do ângulo metodológico, Faoro descreve as ideias políticas à maneira hegeliana, como entes desencarnados universais que teriam potência para organizar a 
Do ponto de vista formal, o campo do PPB é composto por opúsculos, panfletos, cartas, artigos de jornal ou revistas, tratados, manuais, ensaios, dicionários, dissertações, sermões, poemas, músicas, discursos, livros e artigos "que têm por objeto de estudo os aspectos sociais ou políticos substantivos da sociedade brasileira" (Santos, 1970, p.147). Neles, encontram-se "avaliações políticas que alguns homens de percepção educada, comprometidos com o público de uma forma ou de outra, são compelidos a fazer [...] a fim de oferecer uma explicação racional para suas audiências" (Santos, 1970, p.137). Seria fácil aqui declinar pelo menos cem nomes de autores relevantes, que incluiriam escritos de liberais como Evaristo da Veiga e Tavares Bastos; conservadores como Alcindo Guanabara e Campos Sales; monarquistas como Eduardo Prado e o Barão do Rio Branco; positivistas como Miguel Lemos e Teixeira Mendes; nacional-reformistas como Virgínio Santa Rosa e Juarez Távora; integralistas como Plínio Salgado e Miguel Reale; comunistas como Astrogildo Pereira e Otávio Brandão; desenvolvimentistas como Álvaro Vieira Pinto e Roland Corbisier; etc. A produção do PPB como ideologia jorra diariamente nos editoriais de jornais, blogs políticos, comícios, pronunciamentos televisivos e discursos parlamentares. Sua modalidade mais prestigiosa parece a análise de conjuntura feita para intervenção no debate público. Tornou-se função, tanto de jornalistas como Merval Pereira, Mino Carta, Paulo Henrique Amorim e Reinaldo Azevedo, quanto de acadêmicos como Marcos Nobre, Marco Aurélio Nogueira e André Singer.

Do ponto de vista material ou substantivo das ideologias, a percepção de seus autores de se encontrarem na atrasada periferia ibero-americana conferiu ao PPB uma conformação temática e estilística específica. Depen-

realidade política de qualquer parte do mundo. Do ponto de vista ideológico, sua interpretação do Brasil pertence à tradição liberal doutrinária, ou "idealista constitucional"(Santos, 1978; Brandão, 2007), bacharelesca, e apresenta suas típicas dicotomias: sociedade versus Estado; modernidade versus pré-modernidade; liberalismo versus absolutismo; cultura ocidental ou europeia versus cultura oriental ou ibérica. Por fim, o conceito de pensamento político é reduzido a sinônimo de liberalismo, dependendo a sua "autenticidade" da existência, onde ele estivesse, de uma sociedade civil madura e organizada à moda anglo-saxã. No fim das contas, as exigências impostas por Faoro para um "pensamento político" nacional o inviabilizam para países situados fora do Atlântico Norte. Sem sociedade ocidental madura, não haveria modernidade, nem liberalismo autêntico, nem pensamento político. Em sociedades não democráticas, ou julgadas insuficientemente maduras, o liberalismo - e, por extensão, todo o pensamento político - não passaria de enganação ou simulacro. Uma abordagem abrangente e compreensiva do PPB não pode adotar semelhante perspectiva eurocêntrica e essencialista das ideias políticas. Deve concebê-las, ao contrário, no contexto dos diferentes momentos da construção nacional de sua sociedade periférica, tendo em vista os desafios e as possibilidades de ação inscritas em cada um deles. 
dentes dos modelos culturais europeus, que hierarquizavam e definiam os lugares e os papéis das nações a partir de uma concepção evolucionista e teleológica do processo histórico, nossas elites internalizaram o pressuposto de sua subalternidade e de seu atraso de modo a estruturar toda a sua cultura política. Toda ou quase toda a sua produção intelectual está assim relacionada de alguma forma com a constatação do atraso existencial do país diante de outra realidade, aquela do "Primeiro Mundo", identificado como o polo positivo dessa relação especular, porque associado ao moderno (Lynch, 2013a). Em decorrência disso, o eixo temático do PPB gira basicamente em torno do diagnóstico do atraso, da barbárie, do retardo ou do subdesenvolvimento nacional e do imperativo do progresso, da civilização, da evolução ou do desenvolvimento, meios conducentes à transformação das estruturas herdadas da colonização para alcançar a modernidade cêntrica. A esse imperativo modernizador subordinaram-se quase sempre três tópicos maiores da teoria política, relativos ao problema da organização da ordem pública, da liberdade individual e da igualdade social. Estes acabaram menos valorizados em si mesmos do que em virtude de sua associação com o ideal de modernidade erigido na periferia à condição de razão de Estado. Mas não foi apenas o eixo temático do nosso pensamento que adquiriu conformação especial: o estilo de redação também. Já que raramente se viram pertencendo à civilização em que se produzia a "verdadeira" teoria, ciência ou filosofia, nossos escritores preferiram voar mais baixo do ponto de vista da abstração ou da pretensão teórica. O resultado foi um "estilo periférico" de redação e argumentação que contrasta singularmente com aquele, "cosmopolita" ou "universal", que caracteriza as obras canônicas da teoria política europeia ${ }^{4}$.

A primeira característica desse estilo periférico do PPB é o menor grau de generalização e maior sentido prático das reflexões políticas. Na periferia, não se cogita que a elaboração intelectual local tenha alcance universal. Pensada para impactar de modo mais restrito no tempo e no espaço, num ambiente carente de mudanças, ela costuma ter objetivos mais pontuais e

4 Não se pretende aqui caricaturar o pensamento político europeu como sempre vazado em linguagem universalista ou abstrata. A ênfase da referida comparação do PPB com as obras canônicas da teoria política não é ociosa. Penso aqui nos grandes tratados, como o Leviatã de Hobbes, o Segundo tratado de Locke, Do contrato social de Rousseau, os Princípios de política de Constant, Da liberdade de Stuart Mill, O indivíduo contra o Estado de Spencer etc. Importa notar, todavia, que se há obras fundamentais do pensamento europeu redigidas em estilo "contingente", como as Reflexões de Burke ou O que é o terceiro Estado de Sieyès, pouquíssimas foram escritas na periferia em estilo "cosmopolita". 
pragmáticos. A esse respeito, Cruz Costa já afirmava em 1956 que "a nossa origem, as condições de nossa formação, a nossa experiência histórica, nos afastam do alcantilado das metafísicas e nos impelem para a meditação das realidades concretas e vivas" (Costa, 1956). Isso não quer dizer, repita-se, que não haja uma teoria geral implícita naqueles escritos. Ela muitas vezes existe, com efeito, mas precisa ser deduzida ou reconstruída para ser compreendida à maneira "cosmopolita". A segunda característica é a maior centralidade da retórica, da oratória e do argumento de autoridade (Carvalho, 2000). Os autores periféricos leem os cêntricos como autoridades que lhes poupariam o trabalho de descobrir por si mesmos a verdade da arte e da ciência; da mesma forma, a referência às obras europeias conferia prestígio a quem a fazia, sendo demonstração de cultura e capacidade intelectual. Em 1843, o senador Paula Sousa caracteristicamente explicava: "Eu, que não tenho gênio nem capacidade, gosto muito de apoiar-me nas opiniões dos grandes homens, gosto de seguir o exemplo das grandes nações e dos grandes homens" (ASI, 6/5/1843). Exatamente um século depois, Oliveira Viana lamentava aquela atitude, marca de todo o nosso pensamento social: "Ninguém é, aqui, pontífice por si mesmo. Para influir, para 'pesar', para ter autoridade, é-lhe preciso um reforço estranho, um apoio alheio, que não é outro senão o da autoridade do autor estrangeiro" (Vianna, 1991, p. 360).

Esse prestígio do autor estrangeiro é responsável pela terceira característica do estilo periférico: a tendência de os autores nacionais se apresentarem como pioneiros da modernidade cêntrica, obscurecendo as relações de continuidade intelectual com seus predecessores nacionais. Esse traço foi referido já no século XIX por Sílvio Romero, aliás com conhecimento de causa: "A leitura de um escritor estrangeiro, a predileção por um livro de fora vem decidir da natureza das opiniões de um autor entre nós" (Romero, 1969, p. 32). O fato levava Tobias Barreto a reclamar pouco depois que "a ciência não pode ser semelhante à teia de Penélope, que desmanchava durante a noite o que fizera durante o dia" (Barreto, 1977b). Em 1953, Hélio Jaguaribe ainda notava que "cada geração repetia, a partir do marco zero, o esforço da geração anterior, e ia buscar as ideias na Europa” (Jaguaribe, 1957, p. 18). A verdade é que a continuidade entre os autores nacionais existe, devendo ser procurada, não tanto nas suas expressas filiações autorais exógenas, mas naquelas ocultas, endógenas, perceptíveis pela constância temática. A quarta característica digna de nota é a maior diluição das posições extremadas - isto 
é, demasiado conservadoras ou radicais - comparativamente àquelas dos países europeus (Ricupero, 2010). O fenômeno se deve a quatro fatores: a ausência de tradições fortes de um passado feudal e católico; a crença na previsibilidade do futuro (que era aquele dos países cêntricos, tal como enxergado da periferia); a menor complexidade aparente da sociedade local, avessa às hierarquias formais; e, por fim, o quase consenso em torno da necessidade de superação do presente indesejável para alcançar aquele futuro "civilizado" identificado com o presente dos países cêntricos. "Na América, e mais particularmente no Brasil, todos são democratas; todos são liberais [...]. Mesmo os representantes do espírito conservador, real ou fictício, puseram sempre grande empenho em fazer crer que eram eles os verdadeiros liberais", escrevia Assis Brasil (1895, p.160).

O quinto traço do estilo periférico do PPB vincula-se ao anterior e reside na orientação acentuadamente prospectiva da política. O passado é visto negativamente como a época de gestação das mazelas a serem superadas. Já o futuro é o lugar da redenção nacional, a se alcançar pelo progresso, pela civilização, pela evolução, pela modernização, pelo desenvolvimento. Durante a Regência, Gonçalves de Magalhães escreveu: "O tempo, prosseguindo em sua marcha, irá mostrando qual é o destino que a Providência tem marcado a este Império da América" (Magalhães, 1865, p. 144). No começo da República, Euclides da Cunha exprimiu o dilema em que a referida orientação punha urgentemente o país: "Estamos condenados à civilização. Ou progredimos, ou desaparecemos" (Cunha, 1975). A hipertrofia do horizonte de expectativas políticos resultou simetricamente numa atrofia do peso conferido ao espaço de experiências, ou seja, realizou-se à custa do prestígio das tradições políticas, associadas geralmente ao atraso - daí a profusão dos modismos e novidades estrangeiras. Em 1955, Guerreiro Ramos aludia ao fenômeno: "A tradição, a famosa tradição, que impõe tantos limites à vida europeia, se evapora no trópico e mesmo os simples costumes cotidianos sofrem forçosas aberrações e adaptações" (Ramos, 1960, p. 94). A sexta característica do estilo periférico reside na abundância de "projetos nacionais" dependentes da aclimatação de modelos cêntricos. Parte nada desprezível dos escritos do PPB deposita uma grande confiança na importação de instituições políticas de países como a Inglaterra, a França e os Estados Unidos como método de aceleração da modernização social, como a monarquia constitucional, o unitarismo, o parlamentarismo, a república, o federalismo, o presidencialis- 
mo, o judiciarismo, a representação classista, as comissões parlamentares, o mandado de injunção, o júri etc. Não se trata de patologia, mas de estratégia de construção nacional, conforme notado por Guerreiro Ramos: "Não caminhamos do costume para a teoria; do vivido, concreta e materialmente, para o esquema formal. É o inverso que se dá; caminhamos, até agora, no tocante à construção nacional, do teórico para o consuetudinário, do formal para o concretamente vivido. O formalismo é, nas circunstancias típicas e regulares que caracterizam a história do Brasil, uma estratégia de construção nacional" (Ramos, 1966, p. 389-90).

Consequência direta do formalismo institucional, a sétima característica do estilo periférico do $\mathrm{PPB}$ reside no pedagogismo, decorrente da necessidade de se educar a população nas culturas necessárias à boa prática das instituições transplantadas ou por transplantar: o constitucionalismo, o republicanismo, a democracia, o socialismo etc. $\mathrm{O}$ mais célebre pedagogo brasileiro foi Rui Barbosa, que em 1893 declarou, a respeito do constitucionalismo republicano, recém-implantado, mas ineficaz: "É nas classes mais cultas e abastadas que devem ter o seu ponto de partida as agitações regeneradoras. Demos ao povo o exemplo, e ele nos seguirá" (Barbosa, 1931, p. 140). Mas o pedagogismo não foi apanágio dos liberais. Em pleno Estado Novo, Oliveira Viana chamava a atenção para a necessária educação das elites brasileiras para o sentido coletivo da existência, a fim de retirá-las do seu egoísmo e habituá-las a servir à nação (Viana, 1974b, p. 64). À esquerda também se praticou o pedagogismo. Em 1967, Roland Corbisier atribuía o fracasso das reformas de base por terem faltado, "aos próprios reformistas, formação ideológica e clara consciência do problema" (Corbisier, 1968, p. 2). As características desse estilo periférico não são nem boas ou más em si, nem imutáveis. O que se tem verificado é, ao contrário, a tendência de esmaecerem progressivamente, conforme a sociedade brasileira se torna mais moderna e adquire maior autonomia intelectual.

\section{O pensamento político brasileiro como objeto: sentido estrito}

Em sentido estrito, a expressão PPB designa um conjunto mais reduzido de obras mais abrangentes, sistemáticas ou abstratas, que comporia o cânone dos "clássicos" do nosso pensamento político, deixadas por nossos principais pensadores políticos. Uma lista abrangente mas não exaustiva de nomes componentes desse cânone incluiria Hipólito da Costa, o Visconde 
de Cairu, Evaristo da Veiga, Justiniano da Rocha, João Francisco Lisboa, o Visconde de Uruguai, José de Alencar, Joaquim Nabuco, Sílvio Romero, Assis Brasil, Manuel Bonfim, Rui Barbosa, Alberto Torres, Oliveira Vianna, Gilberto Amado, Azevedo Amaral, Francisco Campos, Caio Prado Junior, Hélio Jaguaribe, Sérgio Buarque de Holanda, Guerreiro Ramos, Victor Nunes Leal, Afonso Arinos de Melo Franco, Celso Furtado, Golbery do Couto e Silva, Raimundo Faoro, Florestan Fernandes etc. As obras de tais autores, geralmente materializadas em algum livro reputado clássico, seriam as expressões mais elevadas daquilo que se pode entender como a teoria política e/ou uma ciência política brasileira, no significado que essa última expressão possuía antes da institucionalização universitária ${ }^{5}$. A referência algo fluida entre a teoria e a ciência é propositada, porque as diferenças entre uma e outra só foram estabelecidas a posteriori. Uma vez que o desenvolvimento da ciência política está ligado àquele da história das ideias e das doutrinas, só muito lentamente a noção de ciência objetiva se desligou dos conceitos éticos e das crenças, ou seja, da ideologia (Duverger, 1976, p. 39). No fundo, todas ou quase todas as obras canônicas do PPB pretenderam influenciar o processo político. Refletiram o dilema insolúvel da ciência política: ser entendida como uma disciplina aplicada, voltada para a resolução de determinados fins práticos, ou uma disciplina pura, que descrevesse o fenômeno político independentemente de comprometimento com valores (Gunnell, 1993, p. 5). O que as distingue a esse respeito, portanto, é uma questão de grau: algumas se acharam mais voltadas para a intervenção do que outras, que se detiveram mais na descrição da realidade. Por esse motivo, apenas em sentido aproximado será possível aqui classificar as principais obras do PPB como mais normativas ou pragmáticas do que desinteressadas ou científicas. $\mathrm{O}$ seu valor deve ser medido à luz dos sucessivos paradigmas do que fosse a ciência política, ao longo das três principais etapas nas quais a história do PPB pode ser dividida.

O primeiro período da história do $\mathrm{PPB}$ coincidiu com o primeiro meio século de vida independente do país. Desenvolvida por Montesquieu, Burke, Constant e Tocqueville, a ciência política oitocentista era conside-

5 Da inexistência do campo universitário da ciência política antes de 1969 não se infere sua falta no período anterior. A definição do que seja ciência ou objetividade, como qualquer outra, varia inexoravelmente conforme contingências de tempo e o lugar (Camic, 1995). A própria ideia de uma ciência política anterior à institucionalização confirma a tese. 
rada uma ciência prática: tratava-se da clássica "arte de governar os povos" que deveria orientar o agir político dos estadistas e envolvia a articulação de saberes antigos, como a filosofia moral, e outros novos, como o direito constitucional comparado e a economia política. Mirando-se no exemplo de estadistas como Robert Peel, Palmerston, Thiers e Guizot - os políticos do Império estudavam as instituições e práticas dos países cêntricos (Grã-Bretanha, França e Estados Unidos) para fomentar o progresso e elevar ou manter o Brasil na órbita da civilização. Na qualidade de centro e motor da civilização, a Europa era vista pela periferia ibero-americana como uma espécie de câmara de antevisão do futuro, a partir da qual ela extraía lições a serem aproveitadas, promovendo inovações desejadas e postergando ou antecipando as indesejáveis. Em 1843, o senador Paula Sousa explicou: "Nós nascemos ontem; passamos do estado de colônia para governo representativo; a nação de que fazíamos parte e de quem éramos colônia [Portugal] não tinha governo representativo; era escrava [i.e. absolutista] e até muito atrasada na escala da civilização. Logo, para marcharmos, havemos de tomar por modelo e por norte essa grande nação [a Inglaterra], que lutou séculos para conseguir o governo representativo, e que desde 1688 o tem estável e glorioso" (ASI, 5/7/1843). Para bem cumprir aquela função, liam as obras de doutrinadores, historiadores e constitucionalistas estrangeiros e acompanhavam pelos jornais e revistas que chegavam da Europa tudo o que se relacionava com "a marcha da civilização".

Nem tudo, porém, era consenso. Entre os estadistas do Império, grassavam diferenças acerca do tipo de ciência política que convinha para incorporar ao Brasil as conquistas da civilização refletidas nas instituições europeias ou norte-americanas. Os liberais adotavam uma orientação idealista, cosmopolita e moralista, considerando a ciência política um conjunto de regras imutáveis, universais e eternas: "Há princípios a priori, anteriores aos fatos que os regem, e são estes o que constituem a ciência”, declarou o senador Feijó (ASI, 27/5/1839). Já os conservadores preferiam uma abordagem realista ou cética, que separava a moral da política e os levava a se orientarem pela prudência, ou seja, pelas circunstâncias e pela experiência. Era o caso de Bernardo Pereira de Vasconcelos: "Se a política tivesse regras certas e de uma aplicação invariável, seria, sem dúvida, uma ciência ao alcance de todos; mas a dificuldade de aplicar as regras, de modificá-las, de acomodá-las ao estado social, é o que torna a ciência política a mais difícil de todas 
as ciências e que faz com que todos os publicistas de boa-fé reconheçam que é a que está mais na sua infância" (ASI, 28/5/1839). Era preciso olhar para as circunstâncias particulares do Brasil, adotando, por conseguinte, um ponto de vista político nacional: "As instituições são próprias do lugar e do tempo; devem ser acomodadas não só aos povos, como também às épocas. Cada época tem a sua necessidade apropriada", pontificou Vasconcelos (ASI, 19/6/1840). Os livros mais representativos do período foram, provavelmente: Partidos e eleições no Maranhão, de João Francisco Lisboa (1852); Ação, reação e transação, de Justiniano José da Rocha (1855); Ensaio sobre o direito administrativo, do Visconde de Uruguai (1862); e O abolicionismo, de Joaquim Nabuco (1884). Já a obra que mais se aproximou do ideal teórico puro foi o sistema representativo, de José de Alencar, dedicada que foi em expender, de forma sistemática e com todos os seus desdobramentos, o "princípio da representação, base de que decorre toda a constituição do Estado, raiz e tronco da organização política” (Alencar, 1868, p. 11).

$\mathrm{O}$ segundo período do $\mathrm{PPB}$ correspondeu àquele do cosmopolitismo periférico da nossa belle époque. Sua novidade teórica residiu na introdução das concepções "científicas" da política, extraídas da filosofia da história positivista de Comte ou evolucionista de Spencer, quando do alargamento da esfera pública para o padrão oligárquico da Primeira República (Santos, 2013). Embora os "científicos" fossem bastante moralistas, foram eles que assentaram a tese de que a ciência política se diferenciava pela objetividade com que conduzia a análise dos fenômenos sociais. Alberto Sales, autor de Ciência política (1890), ambicionava caracteristicamente criar uma "política científica" voltada para o combate da "anarquia mental" no Brasil; só ela poderia "banir a revolução, sem excluir o progresso, e estabelecer o reinado da ordem e da paz, sem voltar ao passado" (Sales, 1882, p. 17). Também Manuel Bonfim apelaria à ciência política emulada da biologia para lhe conferir um instrumental capaz de revelar as razões do atraso ibero-americano em América Latina: males de origem (1900). Mas havia outro tipo de ciência política que, embora desdenhada pelos "científicos", atualizava a antiga concepção prudencial baseada na observação e na experiência histórica. Era aquela praticada na Itália por Gaetano Mosca, liberal realista para quem "fazer ciência política quer dizer principalmente se opor a toda a forma de utopismo" (Bobbio, 1996, p. XV). Emblemática dessa orientação no Brasil foi Balmaceda (1896), obra na qual Joaquim Nabuco atacava o autoritaris- 
mo dos científicos: "Certas leis existem em política que se podem chamar científicas, no sentido em que a economia política, a moral, a estatística, são ciências, mas a política em si mesma é uma arte tão prática como a conduta do homem na vida [...]. Conhecer o seu país, conhecer os homens, conhecer-se a si mesmo, há de ser sempre a parte principal da ciência do homem de Estado" (Nabuco, 1949, p. 39). Como se percebe, se as duas tendências - a cientificista e a clássica - compartilhavam a tese de que a ciência política estava ancorada no conhecimento da história, elas divergiam no modo pelo qual compreendiam o processo histórico como teleológico ou contingente.

Este segundo período foi também marcado pela recepção da noção disciplinar da ciência política, entendida como um objeto de especulação metafísica ou filosófica a ser estudada para fins práticos por especialistas situações fora da política militante. Para a "ciência política" estadunidense de Willoughby, a "teoria do Estado" germânica de Bluntschili e as "ciências políticas" francesas de Boutmy, a ciência política resultava do estudo de um variado conjunto de disciplinas que conferiam ao estudioso um painel do desenvolvimento histórico, filosófico e jurídico das instituições (Gunnell, 1993, p. 71). Em livros como Cartas de Inglaterra (1896), o mais importante publicista da época, Rui Barbosa, citava profusamente professores ingleses e norte-americanos como Francis Lieber, William Graham Sumner, James Bryce e Charles Beard. A ciência política precisava ser pensada à maneira de Léon Donnat, como uma ciência experimental: "A política não é a ideologia, nem a estética. Não pode ter nem as abstrações ideais da metafísica, nem a inflexibilidade retilínea e absoluta da dialética dedutiva, nem as combinações simétricas da arte. É, por excelência, entre todas, a ciência experimental" (Barbosa, 1964, p. 3). Embora ainda não houvesse cursos de política no Brasil, aquela noção decantou na orientação de alguns escritores políticos, que buscaram pensar as instituições de modo mais teórico que os juristas em geral. Entre estes se destacaram Assis Brasil, autor de República federal (1883), Democracia representativa: do voto e da maneira de votar (1893) e Do governo presidencial na república brasileira (1896); Sílvio Romero, autor de Parlamentarismo e presidencialismo na República do Brasil (1893) e Os partidos políticos e o grupo positivista (1894); Medeiros e Albuquerque, responsável por O regime presidencial no Brasil (1914); e Aurelino Leal, que publicou Parlamentarismo e presidencialismo no Brasil (1914). Era a manifestação entre nós do "velho institucionalismo", entendido como "a análise 
da evolução histórica das instituições formais-legais e das ideias a elas associadas" (Rhodes, 2006, p. 91). O mais comum, porém, eram obras elaboradas na linha tênue do direito constitucional, como foi o Regime federativo e a república brasileira (1900), de Amaro Cavalcanti.

Durante o terceiro momento do PPB, que começa em torno de 1920 e corresponde à parte mais característica do século XX, percebe-se, no bojo do nosso nacionalismo periférico, uma reação definitiva à ciência política entendida como técnica de direito constitucional manejada dedutivamente pelo estadista culto, à maneira dos juristas. Assimilou-se a noção, difundida pela ciência política norte-americana e pela sociologia política francesa, de que o estudo das instituições não poderia ser desvinculado do comportamento dos atores políticos. Ao mesmo tempo, a chamada "questão nacional" (Oliveira, 1990) voltaria o nosso pensamento para a promoção da eficácia política e administrativa indispensável ao fortalecimento da nacionalidade contra a ameaça representada pelo imperialismo de todos os tipos. Nesse campo, destacaram-se na primeira metade do século os dois grandes nomes do pensamento nacionalista, ou nacional-reformista: Alberto Torres, autor de A organização nacional (1914) e O problema nacional brasileiro (1914); e seu principal discípulo, Oliveira Vianna, autor de O idealismo da Constituição (1927), Problemas de política objetiva (1930) e Instituições políticas brasileiras (1949). Ambos mobilizavam a sociologia como ciência auxiliar para superar o formalismo do período anterior e elaborar uma ciência política pragmática, voltada para a apreensão e transformação da realidade nacional. Torres definia a ciência política como a "arte nuclear de todas as outras, arte de coordenação e de harmonia, arte central, destinada a envolver, a ligar, a impulsionar, a superintender o funcionamento das demais" (Torres, 1914, p. 130). Ela deveria resultar "do estudo racional dos dados concretos da terra e da sociedade, observados e verificados pela experiência" (Torres, 1914, p. 130). Em Instituições políticas brasileiras (1949), Oliveira Viana não destoaria de Torres ao declarar com todas as letras que a ambição de sua vida havia sido a de colocar "a ciência social a serviço da ciência política" (Vianna, 1999, p. 405) 6 .

6 De acordo com Gilberto Amado (1999, p. 156), Alberto Torres e Oliveira Viana pertenceriam a "um partido antissentimental, que chamaríamos científico, pequeno partido que desejaria aplicar ao governo do Brasil as regras da ciência política, segundo as quais um país tropical, situado na latitude do nosso, deve ser governado como os países coloniais, que ficam em latitude semelhante, ainda que ressalvando a dignidade nacional e o patrimônio espiritual de um povo independente". 
Depois da Segunda Guerra, o futuro autor de Formação econômica do Brasil (1958), Celso Furtado, introduziria o pensamento econômico da Comissão Econômica para a América Latina (Cepal), que dali por diante concorreria com a sociologia na qualidade de saber auxiliar da nossa "velha" ciência política. Em nenhum grupo de intelectuais aquela concepção se expressou de forma tão característica quanto naquele que se reuniu inicialmente em torno do ideal nacional-desenvolvimentista do Instituto Superior de Estudos Brasileiros (Iseb). Os mais notáveis foram Hélio Jaguaribe, responsável por Desenvolvimento econômico e desenvolvimento político (1962), e Guerreiro Ramos, autor de A crise do poder no Brasil (1961) e Mito e verdade da revolução brasileira (1963). Ambos deram seguimento à ciência política pragmática perseguida na primeira metade do século por Alberto Torres e Oliveira Vianna. Outro não era o propósito do conceito de ideologia por eles mobilizado, destinado a fornecer às classes progressistas uma "fundamentação teórica" do processo de industrialização em curso que também lhe servisse de justificativa pública (Jaguaribe, 1955, p. 22). Ela funcionaria como uma "teoria da sociedade brasileira que sirva de suporte à estruturação efetiva das tendências de autodeterminação vigentes hoje em nosso país" (Ramos, 1995, p. 60). A onda marxista do começo da década de 1960 atingiria jovens militantes nacionalistas do Iseb como Wanderley Guilherme dos Santos, autor de Quem dará o golpe no Brasil (1962) e Introdução ao estudo das contradições sociais no Brasil (1963). Na USP, porém, a ciência política marxista oriunda do Grupo do Capital era de outro corte, acadêmica e antinacionalista. Seus representantes mais destacados eram Fernando Henrique Cardoso, autor de Empresário industrial e desenvolvimento econômico no Brasil (1964) e Paula Beiguelman, responsável pelos Pequenos estudos de ciência política (1967). A especialização acadêmica da década seguinte levou os ensaios de interpretação política do Brasil ao ocaso: seus últimos grandes exemplares, feitos já no contexto da universidade, foram A revolução burguesa no Brasil (1974), de Florestan Fernandes; a segunda edição de Os donos do poder (1975), de Raimundo Faoro; São Paulo e o Estado nacional, de Simon Schwartzman (1975) e Liberalismo e sindicato no Brasil, de Luiz Werneck Vianna (1976) ${ }^{7}$ Entre aqueles que no século XX arriscaram obras de ciência mais de-

7 Ultimamente, o interesse suscitado pelos "intérpretes do Brasil” levou alguns colegas a redescobrirem o gênero. Foi o caso de Francisco Weffort em A espada, a cobiça e a fé: origens do Brasil (2012) e do economista Luís Carlos Bresser-Pereira em A construção política do Brasil (2014). 
sinteressada ou "pura", destacou-se Gilberto Amado, autor de Eleição e representação (1932). Neste livro, o escritor sergipano estudava o sistema representativo, a representação proporcional e os sistemas partidários, apresentando ao final um capítulo de sociologia política aplicada ao Brasil, à maneira de Gaston Jèze. Não à toa, o subtítulo do livro era Curso de direito político. Amado se apresenta como um perfeito realista: "É um axioma de ciência política verdadeiro em todos os regimes - no regime democrático como nos demais - que a sociedade deve ser dirigida pelos mais avisados (sages); pelos mais inteligentes; pelos mais capazes; pelos melhores; em uma palavra pela elite" (Amado, 1999, p. 11). O pensamento utópico era "uma ideia criminosa que deve ser combatida como um dos maiores males que podem afligir os povos. O que se deve procurar é um justo equilíbrio, o menor mal entre os males, pois os homens não encontraram ainda o meio de realizar, na coexistência social, o paraíso terrestre" (Amado, 1999, p. 29). Dez anos depois, orientado por Paul Arbousse-Bastide, Lourival Gomes Machado defenderia na Faculdade de Filosofia, Letras e Ciências Humanas (FFLCH-USP) sua tese de doutorado intitulada Alguns aspectos atuais do problema do método, objeto e divisões da ciência política (1942). Esta, porém, parece não ter produzido qualquer impacto político ou acadêmico ${ }^{8}$.

Depois da Segunda Guerra, o prestígio da ciência política francesa de publicistas como Georges Burdeau e Maurice Duverger encontrou entre nós o seu zênite, refletido na produção de Victor Nunes Leal e Temístocles Cavalcanti. Em Coronelismo, enxada e voto (1948), Leal explicava a realidade política pela articulação equilibrada de explicações sociológicas, políticas e econômicas, além de recorrer a dados empíricos (Carvalho, 1980, p. 7-8; Lamounier, 1980, p. 51). Cavalcanti, por sua vez autor de Introdução à ciência política (1955), estudava grupos de pressão, metodologia, desenvolvimento, formas de governo e partidos políticos; também presidia o Instituto de Direito Público e Ciência Política da Fundação Getúlio Vargas (IDPCP/FGV-RJ), que editava a revista homônima. Ele reconhecia que, depois da aplicação de "métodos positivos de pesquisa, com o auxílio

8 "Naqueles tempos, a Faculdade costumava publicar boletins, em que se imprimiam as teses ou escritos dos professores ou assistentes. Eram, como não poderia deixar de ser, de tiragem média e circulação limitada, mas marcavam presença no mundo acadêmico. A tese de doutoramento de Lourival versava exatamente sobre objeto e método da ciência política. Nunca quis que circulasse, fosse lida ou comentada. Dela esqueceu porque não representava mais o que pensava, ou porque fosse esforço de aprendiz" (Ferreira, 1994, p. 283). 
dos inquéritos, das estatísticas", a ciência política transcendera o plano das discussões doutrinárias e histórico-jurídicas para abranger "todos os fenômenos que interessam ao comportamento, às instituições, à prática dos regimes, enfim, aos fenômenos que se enquadram na organização, na estrutura, no funcionamento do Estado e no exercício do poder" (Cavalcanti, 1958, p. 45). Enquanto isso, na Universidade de Minas Gerais (UMG, futura UFMG), o também jurista Orlando de Carvalho promovia estudos eleitorais e partidários em Ensaios de sociologia eleitoral (1958) e Os partidos políticos de Minas Gerais e as eleições de 1958 (1959); além disso, fazia da Revista Brasileira de Estudos Políticos um centro de animação para os interessados no campo (Veiga, 1992, p. 59).

Era mais ou menos esse o estado da ciência política brasileira - a "velha" - às vésperas da institucionalização universitária. Considerada a produção da ciência social como um todo, mais da metade dos livros publicados entre 1945 e 1965 versava sobre "pesquisas e reflexões sobre fatos e questões políticas”. A nossa ciência política se debruçara sobre

[...] o processo de escolha dos governantes, focalizando as eleições, o sistema eleitoral e os partidos políticos; seus especialistas analisaram também as ações do setor diplomático e a qualidade da política externa do país; as vantagens e as desvantagens das formas parlamentarista e presidencialista de governo, as forças armadas e a administração político-burocrática do Estado; refletiram sobre as ideologias políticas, privilegiando em suas análises o nacionalismo fundamentado no desenvolvimento econômico; a par disso, investigaram a formação social e histórica do poder político no Brasil (Villas-Boas, 1991, p. 27).

Poucas, entretanto, correspondiam àquilo que nos Estados Unidos se considerava ciência no sentido estrito ou técnico. Era o que lamentava o cientista político estadunidense Robert Packenham (1965): nossa ciência política era ainda basicamente jurídico-constitucional, faltando-lhe até pesquisa de campo. Diagnósticos como esse prepararam o ambiente intelectual para a "nova ciência política" que surgiu quatro anos depois, quando da fundação dos programas de pós-graduação da Universidade Federal de Minas Gerais (UFMG) e do antigo Instituto Universitário de Pesquisas do Rio de Janeiro (Iuperj) - atual Instituto de Estudos Sociais e Políticos da Universidade do Estado do Rio de Janeiro (Iesp-Uerj). 


\section{Pensamento político brasileiro como disciplina acadêmica}

Quando a Unesco apresentou, em 1948, o quadro das quatro rubricas fundamentais da ciência política, incluiu em primeiro lugar a da teoria política, subdividindo-a em teoria propriamente dita e história das ideias. À última cumpre "registrar, analisar e historiar resultados da atividade intelectual, realizada de forma sistemática por camadas ou grupos sociais que se habilitam especificamente para o seu exercício; são utilizados também os termos história do pensamento e história intelectual" (Villas-Boas, 2007, p. 86). Tais textos cuidariam "da análise da constituição das ideias, do surgimento e recepção das mesmas em determinado contexto histórico e da relação entre intelectuais, suas ideias e sua trajetória política e social" (Villas-Boas, 2007, p. 86).

No contexto da ciência política brasileira atual, o campo do PPB corresponde àquele relativo à disciplina de história das ideias no Brasil, dedicada a estudar o objeto descrito na seção anterior como ideologia no sentido lato e teoria e/ou a "velha" ciência política brasileira, no estrito. Foi na década de 1860, quando se começou a questionar o modelo político "regressista", implantado vinte anos antes (Lynch, 2015), que a sociedade brasileira passou a se considerar dotada de um passado autônomo a cuja experiência poderia recorrer para interpelar politicamente o presente. $\mathrm{O}$ hábito de historiar as ideias políticas surgira como atividade auxiliar do legislador imperial, destinada a esclarecer-lhe a posição tomada por seus antecessores a respeito de assuntos sobre os quais ele deveria voltar a se pronunciar. Os primeiros e fragmentários ensaios de histórias do PPB apareceram na forma de inventários das opiniões de parlamentares das gerações anteriores a respeito de temas como centralização, poder moderador, federalismo e escravidão. Elas eram extraídas da principal fonte de publicidade dos debates políticos daquela época, os anais parlamentares, e foram compiladas em obras como o Ensaio sobre o direito administrativo (1862), do Visconde de Uruguai, e O abolicionismo (1883), de Joaquim Nabuco. Este seria ainda responsável pela história constitucional do Segundo Reinado, no sentido oitocentista da expressão, nos três volumes de sua obra-prima: Um estadista do Império (1897). Previsivelmente, as primeiras tentativas mais sistemáticas de historiar o PPB vieram a lume na forma de histórias constitucionais propriamente ditas: A Constituinte perante a história (1863), do barão Homem de Melo; a História constitucional do Brasil (1915), de Aurelino Leal; e Formação cons- 
titucional do Brasil (1914) e A Constituinte republicana (1920), de Agenor de Roure. Acompanhando o clima nacionalista, apareceram nas décadas de 1930 e 1940 os primeiros livros destinados a apresentar os grandes nomes da intelectualidade brasileira. Entre aquelas que deram destaque ao PPB, estavam Inteligência do Brasil, de José Maria Belo (1935), e Orientações do pensamento brasileiro, de Nélson Werneck Sodré (1942). Entretanto, uma disciplina destinada ao estudo do pensamento brasileiro para além da literatura levou tempo a se materializar, devido à convicção típica da América ibérica de que países periféricos não produziam nem ciência nem teoria de valor, mas apenas um "pensamento social", de natureza episódica e conjuntural (Zea, 1956, p. 106).

Essa crença só começou a ser questionada de modo mais enérgico na década de 1950, quando, na esteira da especialização universitária dos estudos brasileiros promovida por filósofos e sociólogos, começou a se falar na existência de um "pensamento social brasileiro" de marcada expressão política. Foram então publicadas as primeiras histórias destinadas a sugerir apresentá-lo, explicá-lo e inventariá-lo: Esforços de teorização da realidade brasileira politicamente orientados de 1870 aos nossos dias, de Guerreiro Ramos (1955); Contribuição à história das ideias no Brasil, de Cruz Costa (1956); e O Brasil no pensamento brasileiro, de Djacir Menezes (1957). Da autoria de Guerreiro foram os três primeiros estudos sobre o PPB orientados por critérios específicos das ciências sociais: $A$ ideologia da jeunesse dorée (1955), O inconsciente sociológico (1956) e A ideologia da ordem (1961). Para os marxistas, todavia, o propósito de se historiar o passado intelectual passava por denunciar o caráter alegadamente retrógrado e autoritário da nossa sociedade, escamoteado pelo véu de ideologias de classe. Foram exemplares dessa perspectiva: O caráter nacional brasileiro: história de uma ideologia, de Dante Moreira Leite (1954); Ideologia do colonialismo: seus reflexos no pensamento brasileiro, de Nélson Werneck Sodré (1961); e Ideologia da cultura brasileira, de Carlos Guilherme Mota (1977). Foi também nessa mesma época que juristas e filósofos entregaram as primeiras obras gerais sobre o PPB: História das ideias socialistas no Brasil, de Vamireh Chacon (1965); História das ideias políticas no Brasil, de Nélson Saldanha (1967); Interpretação da realidade brasileira, de João Camilo de Oliveira Torres (1968). A elas seguir-se-iam: As ideias políticas no Brasil, de Afonso Arinos de Melo Franco (1978); Ideologia autoritária no Brasil (1930-1945), de Jarbas 
Medeiros (1978); e Evolução do pensamento político brasileiro, de Vicente Barreto e Antônio Paim (1985).

Quando a área da ciência política se institucionalizou, na década de 1970, foi natural a emergência imediata de um campo disciplinar do PPB. Devido à influência do Iseb sobre a primeira geração de cientistas políticos, formada nos Estados Unidos (Forjaz, 1997), a ruptura com a "velha ciência política" se limitou ao plano metodológico. No plano temático, a "nova ciência política" incorporou a agenda da "velha" e a converteu em uma área de estudos dedicada a historia das ideias políticas no Brasil ${ }^{9}$. Antes de se formarem cientistas políticos nos Estados Unidos, dois dos principais responsáveis pela institucionalização - Wanderley Guilherme dos Santos e Bolívar Lamounier - já estavam empenhados em estudar nossa história intelectual no intuito de compreender as relações entre liberalismo e autoritarismo, cientes de que "os elementos-chave do que chamamos ciência política são, de uma forma ou de outra, derivados das grandes ideologias históricas" (Lamounier, 1980, p. 35). Para aqueles dois scholars, a finalidade da nova disciplina era dupla: permitir ao cientista conhecer a cultura política do país, eventualmente com finalidade crítica, e fornecer hipóteses de pesquisa a serem empiricamente testadas.

A pesquisa de Wanderley Guilherme dos Santos sobre o PPB se encontra em artigos como: "Preliminares a uma controvérsia metodológica" (1965); "A imaginação político-social brasileira’ (1967), "Raízes da imaginação política brasileira” (1970), "Paradigma e história: a ordem burguesa na imaginação social brasileira" (1978); e "A práxis liberal no Brasil: propostas para reflexão e pesquisa" (1978). Tratou-se da pesquisa que fundou o campo de estudos e foi de longe a mais abrangente efetuada na área até hoje, listando milhares de obras publicadas entre 1865 e 1965. Partindo dos trabalhos pioneiros de Guerreiro Ramos, Wanderley sustentava que o principal eixo temático do

9 Para o avanço da ciência política brasileira, concorrera "a existência de uma importante tradição de pensamento político, anterior aos surtos de crescimento econômico e urbanização deste século [XX], e mesmo ao estabelecimento das primeiras universidades" (Lamounier, 1982, p. 407). Bolívar e Wanderley entendiam que"o papel claramente assumido pelo Estado autoritário enquanto condutor do processo de desenvolvimento da sociedade desnudara a insuficiência das explicações sociológicas ou marxistas que reduziam o ideológico e o político ao plano de epifenômenos. A importância dada aos elementos mais conjunturais e ligados ao funcionamento do regime fez com que se reconhecesse no pensamento social e político um problema perfeitamente legítimo e indispensável para a compreensão da vida social. A análise interna dos discursos tornou-se tarefa obrigatória" (Sadek, 1982, p. 7). Redimensionava-se assim o papel da "produção ideológica no conjunto de variáveis responsáveis pela explicação do desenrolar da vida econômica, social e política” (Sadek, 1982, p. 12). 
PPB consistia no desejo de reformar uma realidade percebida como atrasada a fim de torná-la compatível com as exigências de uma democracia capitalista moderna. Seu autor mais clarividente teria sido Oliveira Viana, que percebera que a falta de uma sociedade liberal moderna impunha no Brasil um Estado atuante para criá-la pelo alto. Adotando a sensibilidade ao contexto nacional como critério de classificação (a nacionalidade), Wanderley afirmava a existência de duas principais tradições do PPB: a dos autoritários instrumentais e a dos liberais doutrinários. Os primeiros teriam percebido que, no quadro de uma sociedade fragmentada e autoritária, o Estado representava uma agência para a promoção da mudança social, devendo-se, pois, fortalecê-lo para modernizar o país para atingir o ideal liberal. Já os liberais doutrinários eram cosmopolitas comprometidos com os interesses oligárquicos, que reproduziam a cartilha europeia e norte-americana na crença de que "a rotina institucional criaria os automatismos políticos e sociais ajustados ao funcionamento normal da ordem liberal" (Santos, 1978, p. 51). Wanderley retornaria ao PPB mais tarde em Dois escritos democráticos de José de Alencar (1991), cuja teoria política elevaria à condição das mais importantes escritas durante o século XIX.

Em sua interpretação do PPB para o período entre 1920 e 1945, elaborada em Formação de um pensamento autoritário na Primeira República (1977), Bolívar Lamounier criticava a classificação "nacionalista” de Wanderley Guilherme dos Santos, a quem acusou de incorporar "a autoimagem do próprio pensamento autoritário", que identificava "o fortalecimento do poder público com o desenvolvimento e o progresso social". Substituindo o critério da nacionalidade por aquele da liberdade, Bolívar rebatizava em sua classificação das duas famílias intelectuais do PPB: uma era simplesmente autoritária e a outra, liberal. Os mais ilustres representantes da linha autoritária teriam sido Alberto Torres, Oliveira Viana, Francisco Campos e Azevedo Amaral. A ideologia de Estado postulava um modelo "eminentemente realista" que "favoreceria um autoritarismo pragmático, esclarecido, temporário, cujo verdadeiro e recôndito objetivo muitas vezes escapa até mesmo aos seus beneficiários" (Lamounier, 1977, p. 383). Seus adeptos não eram autoritários instrumentais, como na classificação de Wanderley, mas autoritários tout court orientados por uma "ideologia de Estado" que se contrapunha àquela autenticamente liberal e própria da democracia, cuja matriz era o mercado (Lamounier, 1977, p. 382). Liberais, portanto, teriam sido intelectuais como 
Tavares Bastos, Rui Barbosa e Sérgio Buarque de Holanda, comprometidos com a crítica do autoritarismo. Ao longo das três décadas seguintes, Bolívar desenvolveria e complementaria sua interpretação liberal do PPB contida em outros escritos, como Rui Barbosa e a construção institucional da democracia brasileira (1999), no qual destacava o papel de construtor institucional exercido por aquele jurista, e livros como Tribunos, profetas e sacerdotes: intelectuais e ideologias no século XX (2014), no qual comparava a atuação dos intelectuais brasileiros com os norte-americanos e europeus, cada qual em seu contexto nacional ameaçado pelo autoritarismo. A polêmica envolvendo os dois scholars concorreu para consolidar a subárea do PPB. Em 1978, Bolívar reconhecia prazenteiro: "Hoje, o pensamento político brasileiro é um campo de estudos perfeitamente legítimo e perfeitamente vacinado contra o vírus do esquematismo ideológico" (Lamounier, 1978, p. 11).

No antigo Iuperj, o ensino da disciplina na pós-graduação começou em 1979, cabendo a José Murilo de Carvalho a responsabilidade pela cadeira de Pensamento Político no Brasil. Sugestionado por Wanderley, seu colega de doutorado em Stanford (Carvalho, 2015), José Murilo enveredaria pelo estudo das elites políticas em perspectiva também intelectual, publicando ao longo da década de 1980 alguns dos livros mais importantes de sua carreira: A construção da ordem (1980); Os bestializados (1987); Teatro de sombras (1988); e A formação das almas (1990). O cientista político mineiro também seria responsável por um sem-número de artigos de grande valor, de perfis intelectuais de autores tão diversos quanto Bernardo de Vasconcelos, João Francisco Lisboa, o Visconde de Uruguai, José de Alencar, Rui Barbosa, Miguel Lemos e Teixeira Mendes, Oliveira Viana e Juarez Távora. De relevância é ainda o artigo de alcance mais teórico denominado "História intelectual no Brasil: a retórica como chave de leitura" (2000). A pesquisa de Wanderley Guilherme também repercutiu nas pesquisas que tiveram lugar no Centro de Pesquisa e de Documentação de História Contemporânea do Brasil da Fundação Getúlio Vargas (CPDOC-FGV) durante as décadas de 1970 a 1990 (Oliveira, 1999, p. 154-5). Entre os investigadores que produziram obras e estudos preciosos sobre o PPB no período, destacaram-se: Ângela de Castro Gomes, autora de obra imensa e seminal de historiografia política, da qual se destaca A invenção do trabalhismo (1988); Lucia Lippi Oliveira, responsável por Elite intelectual e debate político nos anos 30 (1980), A questão nacional na Primeira República (1990) e A sociologia do Guerreiro (1995); e Ricardo 
Benzaquen de Araújo, que escreveu Totalitarismo e revolução: o integralismo de Plínio Salgado (1988). Entre 1961 e 1996, a produção acadêmica sobre o PPB nos programas de pós-graduação em ciência política se fazia então principalmente por dissertações de mestrado, já que havia doutorado apenas na USP ${ }^{10}$. Desta vieram as poucas teses defendidas até então.

Tabela 1 - Teses de doutorado sobre PPB defendidas na ciência política entre 1945-1995

\begin{tabular}{|c|c|c|c|c|}
\hline Ano & Nome & Título & Orientador & IES \\
\hline 1961 & Paula Beiguelman & Teoria e ação do pensamento abolicionista & $\begin{array}{l}\text { Lourival Gomes } \\
\text { Machado }\end{array}$ & USP \\
\hline 1974 & Evaldo Amaral Vieira & $\begin{array}{c}\text { O passado no presente: Oliveira Viana e o } \\
\text { Estado corporativo }\end{array}$ & Oliveiros Ferreira & USP \\
\hline 1983 & $\begin{array}{l}\text { Marco Aurélio } \\
\text { Nogueira }\end{array}$ & $\begin{array}{c}\text { Monarquia, Abolição e República: Joaquim } \\
\text { Nabuco e as desventuras do liberalismo } \\
\text { no Brasil }\end{array}$ & Oliveiros Ferreira & USP \\
\hline 1989 & $\begin{array}{c}\text { Walquíria Domingues } \\
\text { Leão Rego }\end{array}$ & Tavares Bastos, um liberalismo tardio & Célia Quirino & USP \\
\hline 1993 & Leonardo Trevisan & $\begin{array}{c}\text { Obsessões patrióticas: origens e projetos } \\
\text { de duas escolas do pensamento político do } \\
\text { Exército brasileiro }\end{array}$ & Oliveiros Ferreira & USP \\
\hline
\end{tabular}

A década de 1990 se iniciou com novas orientações intelectuais no campo. Dentre os diversos frutos da polêmica em torno do livro Espelho de Próspero, de Richard Morse, um teria longeva repercussão no campo do PPB dentro da ciência política: Americanistas e iberistas: a polêmica de Tavares Bastos com Oliveira Viana, do sociólogo político Luiz Werneck Vianna (1991). Argumentando com base em Lenin e Gramsci, Werneck Vianna argumentava que a modernização brasileira se daria sob a forma de uma revolução passiva marcada pela dialética de duas orientações distintas: uma liberal, americanista, representada por Tavares Bastos; outra comunitária, iberista, representada por Oliveira Viana. Oito anos depois, Werneck publicaria um segundo texto de repercussão na área do PPB: Weber e a interpretação do Brasil (1999). Nele, o autor de Liberalismo e sindicato no Brasil revelava o

10 Não foi possível fazer o levantamento das dissertações de mestrado defendidas na área de PPB no período anterior a 1990, quando as teses de doutorado eram raras e o papel que desempenham hoje era cumprido pelas dissertações. Elas permitiriam oferecer ao leitor um panorama mais completo da produção do PPB sob o regime militar e dos desdobramentos das pesquisas em torno do "pensamento autoritário". A tarefa ficará para uma futura atualização do presente balanço. 
quanto as interpretações do Brasil vinham bebendo da sociologia weberiana para explicar a persistência do autoritarismo estatal ou burocrático na vida política brasileira. Foi durante aquele decênio que o número de teses de doutorado, até então episódicas e concentradas na USP, recebeu impulso com a entrada em cena da produção do antigo Iuperj. Se apenas três teses haviam sido defendidas entre 1986 e 1995, o número saltou para dezoito no decênio seguinte, dando início ao crescimento exponencial do campo de estudos na ciência política:

Tabela 2 - Teses de doutorado sobre PPB defendidas na ciência política entre 1996 e 2005

\begin{tabular}{|c|c|c|c|c|}
\hline Ano & Nome & Título & Orientador & IES \\
\hline 1996 & Gilberto Hochman & $\begin{array}{l}\text { A era do saneamento: as bases da política } \\
\text { de saúde pública no Brasil }\end{array}$ & Elisa Reis & luperj \\
\hline 1997 & Heloisa Starling & $\begin{array}{c}\text { Lembranças do Brasil: teoria política, } \\
\text { história e ficção em Grande Sertão: } \\
\text { Veredas }\end{array}$ & $\begin{array}{l}\text { José Murilo de } \\
\text { Carvalho }\end{array}$ & luperj \\
\hline 1997 & Isabel Lustosa & $\begin{array}{c}\text { Insultos impressos: a guerra dos jornalistas } \\
\text { na independência }\end{array}$ & $\begin{array}{l}\text { José Murilo de } \\
\text { Carvalho }\end{array}$ & luperj \\
\hline 1997 & Marcos Chor Maio & $\begin{array}{c}\text { A história do projeto Unesco: estudos raciais } \\
\text { e ciências sociais no Brasil }\end{array}$ & $\begin{array}{l}\text { José Murilo de } \\
\text { Carvalho }\end{array}$ & luperj \\
\hline 1998 & $\begin{array}{l}\text { Luiz Guilherme } \\
\text { Piva }\end{array}$ & $\begin{array}{c}\text { Ladrilhadores e semeadores: a } \\
\text { modernização brasileira no pensamento } \\
\text { político de Oliveira Vianna, Sérgio Buarque } \\
\text { de Holanda, Azevedo Amaral e } \\
\text { Nestor Duarte }\end{array}$ & Boris Fausto & USP \\
\hline 1998 & $\begin{array}{l}\text { Roberto Teixeira } \\
\text { Perez }\end{array}$ & $\begin{array}{c}\text { O pensamento político de Roberto Campos: } \\
\text { da razão de Estado à razão de mercado } \\
\text { (1950-1995) }\end{array}$ & $\begin{array}{l}\text { César Guimarães e } \\
\text { Marcelo Jasmin }\end{array}$ & luperj \\
\hline 1999 & Milton Lahuerta & $\begin{array}{l}\text { Intelectuais e transição: entre a política e } \\
\text { a profissão }\end{array}$ & Gabriel Cohn & USP \\
\hline 1999 & $\begin{array}{l}\text { Rubem Barboza } \\
\text { Filho }\end{array}$ & $\begin{array}{l}\text { Tradição e artifício: iberismo e barroco na } \\
\text { formação americana }\end{array}$ & $\begin{array}{l}\text { Luiz Werneck } \\
\text { Vianna }\end{array}$ & luperj \\
\hline 2000 & $\begin{array}{l}\text { Fernando } \\
\text { Lattman- } \\
\text { Weltmann }\end{array}$ & $\begin{array}{c}\text { Jequitibá em mato miúdo: vocação } \\
\text { intelectual e retórica política em Afonso } \\
\text { Arinos }\end{array}$ & $\begin{array}{l}\text { César Guimarães e } \\
\text { Ricardo } \\
\text { Benzaquen } \\
\text { de Araújo }\end{array}$ & IUPERJ \\
\hline 2000 & $\begin{array}{l}\text { Christiane Vieira } \\
\text { Laidler }\end{array}$ & $\begin{array}{l}\text { As razões da liberdade, ideias liberais, } \\
\text { escravidão e hierarquias. }\end{array}$ & Carlos Hasenbalg & luperj \\
\hline
\end{tabular}


Tabela 2 - Teses de doutorado sobre PPB defendidas na ciência política entre 1996 e 2005 (continuação)

\begin{tabular}{|c|c|c|c|c|}
\hline Ano & Nome & Título & Orientador & IES \\
\hline 2001 & Norma Cortes & $\begin{array}{c}\text { Esperança e democracia: as ideias de Álvaro } \\
\text { Vieira Pinto }\end{array}$ & $\begin{array}{c}\text { Maria Alice } \\
\text { Rezende de } \\
\text { Carvalho } \\
\end{array}$ & luperj \\
\hline 2002 & Bernardo Ricupero & 0 romantismo e a ideia de nação no Brasil & $\begin{array}{l}\text { Gildo Marçal } \\
\text { Brandão }\end{array}$ & USP \\
\hline 2003 & $\begin{array}{l}\text { Marcelo José } \\
\text { Ferraz Suano }\end{array}$ & $\begin{array}{c}\text { A doutrina Góes Monteiro e o pensamento } \\
\text { político brasileiro nos anos } 30\end{array}$ & Oliveiros Ferreira & USP \\
\hline 2003 & $\begin{array}{l}\text { Gabriela Nunes } \\
\text { Ferreira }\end{array}$ & $\begin{array}{l}\text { O Rio da Prata e a consolidação do Estado } \\
\text { imperial }\end{array}$ & $\begin{array}{c}\text { Gildo Marçal } \\
\text { Brandão }\end{array}$ & USP \\
\hline 2003 & $\begin{array}{c}\text { Aleksandro } \\
\text { Eugenio Pereira }\end{array}$ & $\begin{array}{c}\text { O Iseb na perspectiva de seu tempo: } \\
\text { intelectuais, política e cultura no Brasil } \\
\text { (1952-1964) }\end{array}$ & Gabriel Cohn & USP \\
\hline 2004 & Vera Alves Cepeda & $\begin{array}{c}\text { Roberto Simonsen e a formação da } \\
\text { ideologia industrial no Brasil: limites e } \\
\text { impasses }\end{array}$ & $\begin{array}{l}\text { Gildo Marçal } \\
\text { Brandão }\end{array}$ & USP \\
\hline 2004 & $\begin{array}{l}\text { Maria Fernanda } \\
\text { Lombardi }\end{array}$ & $\begin{array}{c}\text { A esperança e o desencanto: Silva Jardime } \\
\text { a República }\end{array}$ & Eduardo Kugelmas & USP \\
\hline 2005 & $\begin{array}{l}\text { Antônio Marcelo } \\
\text { Jackson }\end{array}$ & $\begin{array}{c}\text { Tavares Bastos: biografia do liberalismo } \\
\text { brasileiro }\end{array}$ & Marcelo Jasmin & luperj \\
\hline
\end{tabular}

O decênio seguinte também testemunhou novas orientações no campo de estudos do PPB, tanto em matéria de interpretação substantiva quanto de metodologia. A primeira renovação foi promovida na USP por Gildo Marçal Brandão, que, ministrando com Eduardo Kugelmas o curso Temas do Pensamento Político Brasileiro, refundaria o campo de estudos do PPB na instituição ao publicar Linhagens do pensamento político brasileiro (2007). Tratava-se de uma crítica marxista tanto à perspectiva nacionalista, de Wanderley Guilherme dos Santos, quanto à liberal, de Bolívar Lamounier. O projeto retomava a proposta de classificação dos pensadores brasileiros por linhagens, adaptando as denominações elaboradas originalmente por Oliveira Viana: idealismo orgânico e idealismo constitucional. Mas o critério classificatório seguido por Gildo não era o do intelectual fluminense, mas aquele de fundo marxista que pressupunha as ideologias distribuídas por classes sociais, umas mais verdadeiras e progressistas que as outras. Então, o idealismo orgânico acabava equiparado ao conservadorismo período, personificado na obra do próprio Viana; o mesmo 
efeito se passava com o idealismo constitucional, visto como a transposição do liberalismo europeu para o Brasil, cuja expressão arquetípica era a obra de Tavares Bastos. Uma vez que os dois idealismos eram considerados por Gildo ideologias aristocráticas e elitistas, cumpria contrapô-las àquelas de cunho antiaristocrático que teriam sido forjadas pela classe média e pela classe operária brasileira no curso da modernização brasileira. Sugestionado por Antonio Candido, Gildo batizaria a primeira de radicalismo de classe média e a segunda de materialismo de matriz comunista. Outro ponto relevante de sua interpretação dizia respeito à atualidade e utilidade das categorias descritivas de cada linhagem para proceder ao exame da cena contemporânea. Tanto os políticos profissionais quanto os intelectuais públicos se inclinariam para uma ou para a outra. Em outras palavras, as categorias idealismo orgânico, idealismo constitucional, radicalismo de classe média e marxismo de matriz comunista teriam transcendência o bastante para não se limitarem a fins puramente acadêmicos, devendo servir para a crítica da atualidade política por parte dos intelectuais públicos (Brandão, 2007, p. 2010). Com Linhagens do pensamento politico brasileiro, a tradição marxista uspiana passava a dispor de sua própria interpretação do $\mathrm{PPB}^{11}$.

À mesma época, a renovação metodológica no campo de estudos da história das ideias políticas era promovida no Iuperj/Iesp-Uerj por Marcelo Jasmin e João Feres Júnior, pela difusão do contextualismo linguístico de Quentin Skinner e John Pocock e da história dos conceitos de Reinhart Koselleck. O artigo de Jasmin, História dos conceitos e teoria política e social: referências preliminares (2005), e os dois livros organizados com Feres Júnior, História dos Conceitos: diálogos e perspectiva (2006) e Léxico da história dos conceitos políticos no Brasil (Feres Júnior, 2014), veicularam uma perspectiva do PPB encarado, não como arremedo de filosofia europeia, mas como história do pensamento político integrada à experiência política e social dos países ibero-americanos. O adversário a combater era o hegelianismo da velha "história da filosofia política", para o qual as ideias eram seres desencarnados de pessoas históricas de carne e osso, que apenas lhes serviriam de veículo. Para os contextualistas, as ideias são produzidas por agentes historicamente situados orientados pelo propósito polêmico de intervenção no debate público. Para tanto, mobilizavam a retórica e promoviam

11 Pouco antes, um politólogo da velha cepa uspiana, Francisco Weffort, havia publicado uma introdução ao PPB chamada Formação do pensamento político brasileiro: ideias personagens. Pouco ou nada nele, todavia, havia de representativo de sua antiga formação marxista de fundador do Cedec, o que surpreendeu alguns colegas do grupo (Ricupero, 2007). Talvez por esse motivo a obra parece não ter tido a repercussão acadêmica que dela era legítimo esperar. 
inovações semânticas. O estabelecimento do significado dos textos não poderia ignorar as condições de sua produção intelectual, devendo chamar a atenção para o significado cambiante dos vocábulos ao longo do tempo. A essa empreitada se juntariam Ricardo Silva (UFSC), em artigos como "História intelectual e teoria política" (2009) e "O contextualismo linguístico na história do pensamento político: Quentin Skinner e o debate metodológico contemporâneo" (2010); e Christian Lynch, pela tradução e publicação dos artigos metodológicos de Pierre Rosanvallon em Por uma história do político (2010). O programa de renovação metodológica suscitou a reação dos partidários do método filosófico tradicional. Para Gildo Marçal Brandão, a análise dos clássicos não deveria "ser dissociada do debate contemporâneo que lhe é momento e parte constitutiva" (Brandão, 1997, p. 32). Já Renato Lessa (1991) defenderia que a teoria fosse pensada no cruzamento entre "a teoria política, a reflexão filosófica e a teoria literária", e o pensamento de cada autor, considerado "uma modalidade particular de exercício ficcional”. Nesse sentido, Lessa propugnaria em Da interpretação à ciência: por uma história filosófica do conhecimento político no Brasil (2011) um reordenamento da ciência política brasileira, a partir do resgate da tradição ensaística do PPB como teoria e/ou "velha ciência política" anterior ao paradigma institucionalista.

Tabela 3 - Teses de doutorado sobre o PPB na área de ciência política (2006-2015)

\begin{tabular}{|c|c|c|c|c|}
\hline Ano & Nome & Título & Orientador & IES \\
\hline 2006 & $\begin{array}{c}\text { Maria Aparecida } \\
\text { Abranches }\end{array}$ & $\begin{array}{l}\text { Nacionalismo e democracia no } \\
\text { pensamento de Guerreiro Ramos }\end{array}$ & Marcelo Jasmin & luperj \\
\hline 2006 & Ivo Coser & $\begin{array}{l}\text { Visconde do Uruguai: centralização e } \\
\text { federalismo no Brasil }\end{array}$ & Marcelo Jasmin & luperj \\
\hline 2006 & $\begin{array}{l}\text { Rogério Dultra dos } \\
\text { Santos }\end{array}$ & $\begin{array}{c}0 \text { constitucionalismo antiliberal de } \\
\text { Francisco Campos: cesarismo, positivismo } \\
\text { e corporativismo no Estado Novo }\end{array}$ & José Eisenberg & luperj \\
\hline 2007 & $\begin{array}{l}\text { Christian Edward } \\
\text { Cyril Lynch }\end{array}$ & $\begin{array}{l}0 \text { momento monarquiano: o poder } \\
\text { moderador e o pensamento político } \\
\text { imperial }\end{array}$ & Marcelo Jasmin & luperj \\
\hline 2007 & $\begin{array}{l}\text { Cristina Buarque de } \\
\text { Holanda }\end{array}$ & $\begin{array}{l}\text { Modos de representação política: } 0 \\
\text { experimento da Primeira República } \\
\text { brasileira }\end{array}$ & Renato Lessa & luperj \\
\hline 2007 & $\begin{array}{l}\text { Neide Morais de } \\
\text { Mello }\end{array}$ & $\begin{array}{l}\text { Intelectuais na vida pública: Mário de } \\
\text { Andrade e Monteiro Lobato }\end{array}$ & Gabriel Cohn & USP \\
\hline 2007 & $\begin{array}{l}\text { Christiane Jalles de } \\
\text { Paula }\end{array}$ & $\begin{array}{l}\text { Combatendo o bom combate: política } \\
\text { e religião nas crônicas jornalísticas de } \\
\text { Gustavo Corção }\end{array}$ & César Guimarães & luperj \\
\hline
\end{tabular}


Tabela 3 - Teses de doutorado sobre o PPB na área de ciência política (2006-2015) (continuação)

\begin{tabular}{|c|c|c|c|c|}
\hline Ano & Nome & Título & Orientador & IES \\
\hline 2009 & $\begin{array}{l}\text { Carlos Sávio Gomes } \\
\text { Teixeira }\end{array}$ & $\begin{array}{l}\text { A esquerda experimentalista: análise da } \\
\text { teoria política de Unger }\end{array}$ & Fernando Haddad & USP \\
\hline 2009 & $\begin{array}{l}\text { Rubens Goyatá } \\
\text { Campante }\end{array}$ & $\begin{array}{c}\text { Patrimonialismo no Brasil: leituras críticas } \\
\text { de interpretações weberianas e suas } \\
\text { articulações socioculturais }\end{array}$ & Juarez Guimarães & UFMG \\
\hline 2011 & Luísa Rauter Pereira & $\begin{array}{c}\text { História do conceito de povo no Brasil: } \\
\text { revolução e historicização da linguagem } \\
\text { política }\end{array}$ & João Feres Júnior & $\begin{array}{l}\text { lesp- } \\
\text { Uerj }\end{array}$ \\
\hline 2011 & $\begin{array}{l}\text { Diego Rafael } \\
\text { Ambrosini }\end{array}$ & $\begin{array}{l}\text { Contextos de Nestor Duarte: direito, } \\
\text { sociologia e política }\end{array}$ & Bernardo Ricupero & USP \\
\hline 2013 & $\begin{array}{l}\text { Wendel Antunes } \\
\text { Cintra }\end{array}$ & $\begin{array}{l}\text { Qual democracia? } 0 \text { governo do povo no } \\
\text { pensamento político brasileiro }\end{array}$ & Marcelo Jasmin & $\begin{array}{l}\text { lesp- } \\
\text { Uerj }\end{array}$ \\
\hline 2013 & $\begin{array}{c}\text { Marcelo } \\
\text { Sevaybricker Moreira }\end{array}$ & $\begin{array}{l}\text { Raízes intelectuais da democracia } \\
\text { brasileira: linguagens políticas e a } \\
\text { formação da república }\end{array}$ & Juarez Guimarães & UFMG \\
\hline 2013 & Fabrícia Carla Viviani & $\begin{array}{c}\text { Democracia, Estado e indústria: uma } \\
\text { análise do discurso varguista em A Nova } \\
\text { Política do Brasil }\end{array}$ & Vera Alves Cepeda & UFSCAR \\
\hline 2013 & $\begin{array}{l}\text { Carlos Alexandre } \\
\text { Ramos }\end{array}$ & $\begin{array}{l}\text { A democracia no pensamento político dos } \\
\text { comunistas brasileiros (1979-1983) }\end{array}$ & Vera Alves Cepeda & UFSCar \\
\hline 2013 & $\begin{array}{l}\text { Leandro do } \\
\text { Nascimento } \\
\text { Rodrigues }\end{array}$ & $\begin{array}{l}\text { Os caminhos da identidade nacional } \\
\text { brasileira: a perspectiva do etno- } \\
\text { simbolismo }\end{array}$ & $\begin{array}{l}\text { Paulo César } \\
\text { Nascimento }\end{array}$ & UnB \\
\hline 2014 & $\begin{array}{c}\text { Daniel Estevão } \\
\text { Ramos de Miranda }\end{array}$ & $\begin{array}{l}\text { Bresser-Pereira: pensamento como ação } \\
\text { política }\end{array}$ & $\begin{array}{l}\text { Marco Aurélio } \\
\text { Nogueira }\end{array}$ & UFSCar \\
\hline 2014 & Martin Adamec & $\begin{array}{l}\text { A formação da identidade nacional } \\
\text { brasileira: um projeto ressentido }\end{array}$ & $\begin{array}{l}\text { Paulo César } \\
\text { Nascimento }\end{array}$ & UnB \\
\hline 2014 & $\begin{array}{c}\text { André Kaysel Velasco } \\
\text { e Cruz }\end{array}$ & $\begin{array}{l}\text { Entre a nação e a revolução: o marxismo } \\
\text { de matriz comunista e o nacionalismo } \\
\text { popular no Peru e no Brasil (1928-1964) }\end{array}$ & Bernardo Ricupero & USP \\
\hline 2015 & $\begin{array}{l}\text { Diogo Tourino de } \\
\text { Sousa }\end{array}$ & $\begin{array}{l}\text { De um ponto de vista mais geral: a } \\
\text { república como ideal normativo }\end{array}$ & Renato Lessa & $\begin{array}{l}\text { lesp- } \\
\text { Uerj }\end{array}$ \\
\hline 2015 & $\begin{array}{l}\text { Jorge Gomes } \\
\text { Chaloub }\end{array}$ & $\begin{array}{l}0 \text { liberalismo entre o espírito e a espada: } \\
\text { UDN e a República de } 1946\end{array}$ & Marcelo Jasmin & $\begin{array}{l}\text { lesp- } \\
\text { Uerj }\end{array}$ \\
\hline 2015 & Pedro Rego Lima & $\begin{array}{l}\text { As desventuras do marxismo: Fernando } \\
\text { Henrique Cardoso, antagonismo e } \\
\text { reconciliação }\end{array}$ & César Guimarães & $\begin{array}{l}\text { lesp- } \\
\text { Uerj }\end{array}$ \\
\hline 2015 & $\begin{array}{l}\text { André Drummond } \\
\text { Mello Silva }\end{array}$ & $\begin{array}{c}\text { Sem rei e sem escravos: o republicanismo } \\
\text { e as linguagens políticas do abolicionismo } \\
\text { no Brasil }\end{array}$ & Juarez Guimarães & UFMG \\
\hline
\end{tabular}




\section{Retrato atual do campo: mannheimianos, lukacsianos e gramscianos}

Nos últimos dez anos, o número de teses defendidas na subárea de PPB continuou subindo, chegando a 23. Os espaços de debate no âmbito das associações de ciências sociais se ampliaram para dar conta do crescimento. Desde o primeiro Encontro da ABCP, em 1998, o PPB passou a contar com espaço cativo dentro da área temática (AT) de Teoria Política, coordenada por Marcelo Jasmin. A AT autônoma do PPB emergiria quinze anos depois, quando do IX Encontro da ABCP, em Brasília, sob a coordenação de Christian Lynch e Bernardo Ricupero: na ocasião, foram apresentadas 33 comunicações de pesquisadores de todas as regiões do país. No âmbito da Anpocs, em que já se contava com o grupo interdisciplinar de trabalho (GT) de Pensamento Social no Brasil, os pesquisadores do PPB passaram a dispor desde 2007 de um GT de Teoria Política, criado por Gildo Marçal Brandão; quatro anos depois, o GT passaria a se chamar Teoria Política e Pensamento Político Brasileiro. Os investigadores do PPB passaram a dispor, por fim, de um terceiro GT nos encontros da Anpocs, coordenado por Luiz Werneck Vianna e Rubem Barboza Filho: Intelectuais, Cultura e Democracia. Hoje, há teses de doutorado defendidas em sete programas de pós-graduação em ciência política sobre o PPB: Uerj, USP, UFMG, Unicamp, UFSCar, UFF e UnB. Para além da área, o PPB está presente em outros programas, especialmente de ciências sociais, trabalhado por diversos cientistas políticos. No Rio de Janeiro, é possível declinar os nomes de Gilberto Hochman (Fiocruz), João Trajano Sento Sé (Uerj), Rogério Dultra dos Santos (UFF) e Darlan Montenegro (UFRRJ); em São Paulo, os de Milton Lahuerta e Angélica Lovatto (Unesp), Gabriela Nunes Ferreira, Maria Fernanda Lombardi e Diego Ambrosini (Unifesp); em Minas Gerais, o de Rubem Barboza Filho (UFJF); na Bahia, o de Wendel Antunes Cintra (UFBA); na Paraíba, o de José Artigas de Godoy (UFPB); no Ceará, o de Fábio Gentile (UFC); em Santa Catarina, o de Ricardo Silva (UFSC); etc. Como expressão da expansão nos últimos quinze anos, é digno de nota o fato de que, na graduação, a disciplina de PPB tenha sido incluída em 2010 no currículo do curso de ciência política da Universidade Federal do Estado do Rio de Janeiro (Unirio). 
Figura 1 - Teses de doutorado defendidas na área de PPB da ciência política (1975-2015)

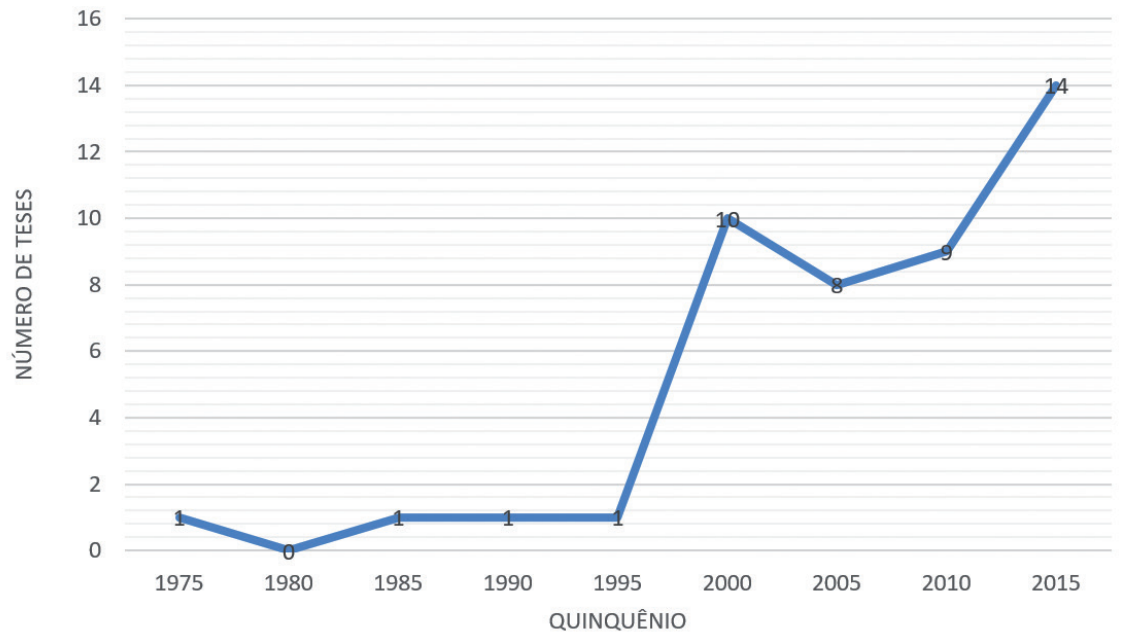

As diversas abordagens do PPB no campo da ciência política envolvem questões semelhantes àquelas da história intelectual. A clivagem mais importante opõe abordagens mais filosóficas ou textualistas àquelas de natureza mais histórica ou contextual. Como tipo ideal, a abordagem textualista oriunda da história da filosofia se concentra em obras reputadas exemplares por sua sistematicidade e abrangência, consideradas "clássicas" por sua capacidade de orientar juízos sobre a realidade atual. A fim de escaparem das limitações inerentes ao contexto político e social de elaboração da obra, os partidários dessa abordagem concentram-se nos argumentos de ordem geral e apresentam alto grau de abstração, dedutivismo e generalização ${ }^{12}$. A abordagem contextualista, por outro lado, tende, como história do pensamento ou das ideias, a não separar o exame do texto da referência à época e à sociedade em que foram produzidas; ela está menos interessada na suposta sistematicidade ou coerência do texto analisado do que em entender como o autor reagia às diferentes interpelações de seu tempo. Essa oposição

12 Embora reconheça "uma inseparável conexão entre filosofia e história"; que "todo filosofar parte da totalidade do passado e se projeta para o futuro, pondo em marcha a história da filosofia", o filósofo Julián Marías ressaltava em 1940 que "a verdade da filosofia" não é indiferente à sua história: a "história da filosofia não é uma mera informação erudita a respeito das fontes dos filósofos, e sim a exposição verdadeira do conteúdo real da filosofia" (Mariás, 2004, p. 7-8). 
entre formas de abordagem mais filosófica ou histórica se reproduziu em toda a parte onde a tradição de estudo do pensamento político se achava consolidada. No mundo anglófono, a história da filosofia política de Leo Strauss concorreu com a história das ideias de Arthur Lovejoy, sucedida pela história do pensamento político de Quentin Skinner e John Pocock. $\mathrm{Na}$ França, a história das doutrinas políticas de Jean-Jacques Chevallier se contrapôs à história das ideias políticas de Jean Touchard e Marcel Prélot. $\mathrm{Na}$ Alemanha, foi a história espiritual de Friedrich Meinecke que sofreu os golpes da história dos conceitos de Reinhart Koselleck ${ }^{13}$. No Brasil, já vimos que a querela entre "filósofos" e "historiadores" repercutiu entre investigadores como Marcelo Jasmin, João Feres e Ricardo Silva, de um lado, e Gildo Marçal Brandão e Renato Lessa, de outro. Na prática, o panorama é mais variado, devido às diferentes tradições institucionais e ao prestígio do marxismo. Mas é possível nomear e descrever, ainda que em linhas muito gerais, os três principais grupos de estudo do PPB em atividade no Brasil. Embora não constituam espaços fechados, eles e seus trabalhos se distinguem por diferentes orientações teóricas e preocupações intelectuais. Nomeá-los-ei levando em consideração suas diferentes referências teórico-metodológicas: são os mannheimianos, os lukacsianos e os gramscianos.

Os mannheimianos prevalecem nos programas do Iesp-Uerj e na UFF. Orientado por uma mundivisão weberiana, no grupo prevalece uma análise do pensamento político que remonta em última análise àquela esposada por Karl Mannheim em Ideologia e utopia. Seus investigadores descendem de uma tradição nacional de história intelectual tributária do Iseb de Hélio Jaguaribe e Guerreiro Ramos, que encontrou modernamente na pesquisa de Wanderley Guilherme dos Santos e nos subsequentes estudos históricos de José Murilo de Carvalho e filosóficos de Renato Lessa os seus mais importantes referenciais. A orientação filosófica é visível em pesquisadores como Cristina Buarque e César Kiraly, que frequentaram o seminário de "Estudos

13 Embora a polêmica continue a grassar, tem prevalecido nos estudos de história intelectual dos países cêntricos um contextualismo matizado, que incorporou as críticas dirigidas à sua versão mais radical (Bevir, 2008). Para os fins do presente balanço, pode-se dizer que, situada em um nível intermediário - aquele da "teoria política" -, o exercício da história do pensamento político deve evitar tanto os excessos da abordagem puramente filosófica, para a qual não existe tempo e espaço, e aqueles da pura história, para a qual é tudo agência e contingência (Klosko, 2011, p. 4). Ainda assim, há espaço para abordagens que se inclinem mais para um lado do que para o outro, conforme o objeto e a natureza da pesquisa a ser empreendida. 
Hum(e)anos" coordenado pelo autor de Veneno pirrônico. Já os “historiadores" formados por Marcelo Jasmin, como Christian Lynch (Iesp-Uerj), Ivo Coser (UFRJ) e Wendel Antunes Cintra (UFBA), ou por João Feres Júnior, como Luísa Rauter (Ufop), procuram na história do pensamento os insumos da produção teórica. Entretanto, sejam "historiadores" ou "filósofos", há em todos eles a marca forte de temas como o do liberalismo, da democracia e do autoritarismo, bem como o interesse crescente pelo pensamento ibero-americano. É o que se extrai da leitura das obras Visconde do Uruguai: centralização e federalismo no Brasil (1823-1866), de Ivo Coser; Modos de representação política: o experimento da Primeira República brasileira (2009), de Cristina Buarque; e Da monarquia à oligarquia: história institucional e pensamento político brasileiro (2014) e Monarquia sem despotismo e liberdade sem anarquia: o pensamento político do Marquês de Caravelas (2014), Christian Lynch. Os pesquisadores orientados por Juarez Guimarães na UFMG, como Marcelo Sevaybricker (UFLA) e André Drummond (UFJF), parecem comungar da mesma perspectiva. Explica-se o fato pelas afinidades de origem do seu Departamento de Ciência Política (DCP) com o antigo Iuperj, decorrentes da mesma referência isebiana e da mesma precoce institucionalização. Um número significativo de seus pesquisadores do DCP-UFMG se transferiria em seguida para o Rio de Janeiro, como o próprio José Murilo de Carvalho, cujas pesquisas haviam começado em Belo Horizonte em 1969 (Veiga, 1992, p. 65). Isso não significa, porém, que o trabalho do grupo mineiro de PPB não guarde cor própria. Ela resulta da preocupação com o tema da república, fundamental na reflexão de outros docentes daquela universidade, como Heloisa Starling e Newton Bignotto. De um modo geral, as afinidades mannheimianas na forma de conceber e tratar o pensamento político os encaminham para o GT de Teoria Política e Pensamento Político Brasileiro da Anpocs.

Os lukacsianos têm o seu quartel-general na USP, instituição na qual há muito o estudo do pensamento brasileiro sofre a influência da abordagem socioliterária inaugurada por Antonio Candido e da visão de mundo marxista que dominou duradouramente o conjunto da FFLCH. Assim, é visível nos escritos de Gildo Marçal Brandão, antigo militante comunista e intelectual público do Centro de Estudos de Cultura Contemporânea (Cedec), o marxismo hegeliano de György Lukács em História e consciência de classe; este foi desenvolvido por Lucien Goldmann para o estudo das ciências sociais 
e aclimatado em São Paulo por seu discípulo, Michael Löwy. O resultado transparece nos escritos que compuseram o livro Linhagens do pensamento político brasileiro (2010). Também Bernardo Ricupero (USP) e André Kaysel (Unila) se revelam interessados na plêiade de autores de esquerda que no passado recente pensavam a política recorrendo menos à ciência homônima do que às áreas em que a influência do marxismo era sentida com mais intensidade, como a sociologia (Florestan Fernandes), a história (Fernando Novaes), a literatura (Roberto Schwarz) e a economia (Celso Furtado). Ricupero tem sua atuação marcada pelo estudo dos "intérpretes do Brasil" em geral, com destaque para Caio Prado, compreendendo-os a partir da teoria da dependência. É o que se extrai dos trabalhos como Caio Prado e a nacionalização do marxismo no Brasil (2000), O romantismo e a ideia de nação no Brasil (2004) e Sete lições sobre as interpretações do Brasil (2007). Tais características o aproximam do GT de Pensamento Social no Brasil, no qual prevalece a concepção "sincrética" de sociologia do já referido Antonio Candido (2006, p. 292). Não deixa de ser curioso, porém, que a maioria dos discípulos de Gildo Marçal, como Gabriela Nunes Ferreira (Unifesp), Maria Fernanda Lombardi (Unifesp), Vera Cepeda (UFSCar) e Diego Ambrosini (Unifesp), tenha se deixado levar por uma leitura não marxista de Linhagens, o que na prática resultou numa abordagem próxima à dos mannheimianos. É o que se depreende de Centralização e descentralização no Império: o debate entre Tavares Bastos e visconde do Uruguai (1999), de Gabriela Nunes Ferreira, e Esperança e o desencanto: Silva Jardim e a República, de Maria Fernanda Lombardi (2008).

Entretanto, o grupo mais capilarizado do PPB hoje é o dos gramscianos. Seus pesquisadores seniores vieram também da militância do comunismo democrático, como os lukacsianos paulistas; sua figura de proa é o sociólogo Luiz Werneck Vianna - ele mesmo, um “intérprete do Brasil”. Sua abordagem do PPB parte de uma interpretação do processo de modernização do país, entendido como um tipo particular de revolução burguesa efetuada na periferia do capitalismo mundial, na forma de uma revolução passiva. Nessa chave, o estudo do PPB constitui um instrumento essencial para se aprender o modo como os intelectuais brasileiros adaptaram as ideologias representativas da modernidade europeia e dos caminhos e descaminhos dessa adaptação. $\mathrm{O}$ marco teórico é aquele delineado por Gramsci em Os intelectuais e a organização da cultura, segundo o qual os escritores políticos são compreendidos 
como intelectuais públicos encarregados de organizar a cultura política para fins hegemônicos ou contra-hegemónicos. Os gramscianos também reúnem sociólogos, como Maria Alice Rezende de Carvalho (PUC-RJ), João Marcelo Ehlert Maia (FGV-RJ) e Fernando Perlatto (UFJF), que pelo caráter "público" de sua sociologia (Perlattto, 2010) não se diferenciam em sua abordagem do pensamento brasileiro de cientistas políticos como Marco Aurélio Nogueira e Milton Lahuerta (UFSCar) e Rubem Barboza Filho e Francisco Raul Magalhães (UFJF). Trata-se do grupo que revela mais apreço pela concepção do acadêmico como intelectual público. Sua marca forte é a da república, abordando os escritores do passado como predecessores cuja vocação para a intervenção no debate público cumpriria emular. As obras de PPB mais representativas do grupo - para além daquelas do próprio Werneck Vianna, já mencionadas - são: As desventuras do liberalismo: Joaquim Nabuco, a monarquia e a república (1984), de Marco Aurélio Nogueira; O quinto século: André Rebouças e a construção do Brasil (1998), de Maria Alice Rezende de Carvalho; Tradição e artifício: ibérico e barroco na formação americana (2000), de Rubem Barboza Filho, também autor do importante artigo "A modernização brasileira e o nosso pensamento político" (2011); e, por fim, Elitismo, autonomia, populismo: os intelectuais na transição dos anos 1940 (2014), de Milton Lahuerta. O GT preferido pelos gramscianos na Anpocs é o já mencionado Intelectuais, Cultura e Democracia.

\section{Conclusão: crítica do campo e desafios para o futuro.}

A despeito da expansão quantitativa da subárea, há problemas e desafios a serem enfrentados pelo campo do PPB que precisam ser encarados para que ele se desenvolva com a qualidade esperada. Em primeiro lugar, a área temática ainda não alcançou o patamar de nacionalização atingida recentemente pela ciência política como um todo (Marenco, 2014; Amorim e Santos, 2015). Nos programas de pós-graduação, as linhas de pesquisa estão concentradas na região Sudeste, ficando diluídas pelo restante do país nos programas de ciências sociais ou de sociologia política. Em segundo lugar, do ponto de vista qualitativo, também há ajustes a serem feitos. A maioria dos trabalhos se concentra naquela dimensão do PPB como estudo de escritores canônicos - os chamados “intérpretes do Brasil”. Essa predominância é compreensível, levando-se em conta que ainda se experimenta um momento de resgate de autores esquecidos ou mal compreendidos. Também me parece inevitável, 
nessa fase, que parte dos trabalhos ainda se caracterize por uma abordagem metodológica deficiente, ou certa preocupação estéril de encaixar autores nesta ou naquela linhagem (esquecendo-se de que essas classificações são apenas mapas gerais da disciplina). Como conjunto de ideologias integrantes da nossa cultura política, há menos trabalhos do que seria desejável. Como quer Pierre Rosanvallon (2010, p. 46), "se certos textos parecem cruciais, não é apenas porque são expressões do pensamento, mas porque eles representam a formalização de um momento histórico, político ou filosófico específico". Uma vez que o objetivo aqui é o de compreender os intelectuais no seio de sua cultura, é preciso também atentar para "o modo de leitura dos grandes textos teóricos, a recepção das obras literárias, a análise da imprensa e dos movimentos de opinião, o destino dos panfletos, a construção dos discursos de circunstância" (Rosanvallon, 2010, p. 86). Em terceiro lugar, também há poucos trabalhos de PPB como "velha ciência política brasileira". Tanto quanto modelos econométricos gerais extraídos da literatura internacional, eles certamente teriam algo com que contribuir para iluminar discussões atuais relativas à reforma política. Deve-se lamentar por igual que praticamente todos os estudos do PPB cuidem quase de maneira exclusiva da política interna. O que se começa a estudar na periferia da ciência política é chamado pensamento diplomático brasileiro - denominação pouco feliz, na medida em que sugere que a tarefa de pensar o lugar do Brasil no mundo seja exclusividade dos diplomatas ${ }^{14}$.

O que parece menos justificável, porém, é a insuficiente aplicação de orientações teórico-metodológicas da própria teoria política ao estudo do PPB. A existência de um campo de estudos do PPB, destacado daquele de teoria política, é fenômeno tipicamente periférico. Embora nada impeça que, nos países cêntricos, haja cursos ou pesquisas sobre o pensamento político de seus autores nacionais, eles lá são sempre pensados como parte integrante da "teoria política"15. Na América ibérica, acontece o contrário; seus pensadores quase nunca se pensam ou são pensados como parte integrante daquela teoria, e por

14 O quadro pode reverter graças a esforços como o de Dawisson Belém Lopes, que recentemente (2014) ofereceu no programa de pós-graduação em ciência política da UFMG um curso sobre o tema, sob a designação mais apropriada de "Pensamento Internacional Brasileiro".

15 Assim, um livro como História do pensamento político em contexto nacional, organizado por Dario Castiglione e lain Hampsher-Monk (2001), induz o estudante brasileiro ao equívoco de imaginar que lá encontrará capítulos sobre pensamento político estadunidense, francês, alemão, italiano etc. Na verdade, trata-se de obra dedicada a compreender as diferentes tradições nacionais de estudo da "teoria política", que é ali pensada como geral e não fracionada em "universal" e "particular". 
isso acabam estudados, quando são, em disciplina à parte. Conforme salienta Marcelo Sevaybricker Moreira, não se trata aqui de "negar ou subestimar as vantagens do processo de divisão social do trabalho intelectual, mas de encará-lo criticamente, alertando para a tendência ainda presente em que teoria e prática política ficam apartadas uma da outra, do ponto de vista da análise, quando se teria muito a ganhar em pensá-las como parte de uma mesma realidade" (Moreira, 2012, p. 87). Outro que pede o fortalecimento dos vínculos da teoria política com o $\mathrm{PPB}$, bem como com a história, inclusive a comparada, além de maior rigor metodológico é Rubem Barboza Filho (Schwarcz e Botelho, 2011, p. 147). É o caso de pensar se o horizonte último da disciplina de PPB não seria o de sua dissolução final na teoria política. Para tanto, será necessário aguardar o dia em que o PPB terá perdido o complexo de inferioridade, e a nossa teoria política, o eurocentrismo que sempre a contaminou. Enquanto esse dia não chega, faço minhas as palavras de Cicero Araujo e San Romanelli:

Urge que a produção da teoria política, propensa a uma salutar elaboração cosmopolita e universalizante, não perca de vista a tradição do próprio pensamento político brasileiro e, mais do que isso, procure recompor os seus fios de modo a propiciar uma compreensão, ao mesmo tempo nacional e internacional, de suas grandes vertentes. Nunca é demais lembrar que essa é a tendência de todas as teorias políticas importantes produzidas alhures, inclusive e especialmente a produzida em língua inglesa, por mais língua franca que pretenda ser. Não se trata aqui de nenhuma queixa patriótica, mas do simples problema institucional de construir potência intelectual e acadêmica suficiente para sair da etapa do predomínio da recepção, para a do (no mínimo) equilíbrio entre recepção e transmissão do que é produzido nas redes globais de conhecimento. Se queremos chegar a esse ponto, não há como deixar de lado a construção de uma comunidade efetivamente integrada; e esta apenas o será na medida em que, simultaneamente, propiciar o diálogo direto entre os autores e sua remissão sistemática ás tradições nacionais. É isso que conferiria massa crítica, especificidade e força de conteúdo, senão a todas, pelo menos a grande parte das contribuições brasileiras que pretendam um impacto universalizante e internacional (Araújo e Assumpção, 2010, p. 78).

\section{Referências}

ASI - ANAIS DO SENADO DO IMPÉRIO DO BRASIL (1939, 1940, 1943 [1978]). Brasília: Senado Federal.

ALENCAR, José de (1868). O sistema representativo. Rio de Janeiro: Garnier. 
AMADO, Gilberto (1999). Eleição e representação. Introdução Olavo Brasil de Lima Júnior. Brasília: Senado Federal.

AMORIM NETO, Octavio e SANTOS, Fabiano (2015). "La ciencia política en Brasil en la última década: la nacionalización y la lenta superación del parroquialismo". Revista de Ciencia Política (Santiago), v. 35, n. 1, p. 19-31. ARAÚJO, Cícero \& REIS, Bruno P. Wanderley (2005). "A formação do pós-graduando em ciência política”, em MARTINS, Carlos Benedito (org.). Para onde vai a pós-graduação em ciências sociais no Brasil. Bauru (SP): Edusc.

ARAÚJO, Cícero \& ASSUMPÇÃO, San Romanelli (2010). “Teoria política no Brasil hoje”, em MARTINS, Carlos Benedito (org). Horizontes das ciências sociais no Brasil: ciência política. São Paulo: Anpocs.

BARBOSA, Rui (1931). "Ruínas de um governo: o governo Hermes, as ruínas da Constituição, a crise moral, a justiça e manifesto à Nação”. Prefácio e notas Fernando Néri. Rio de Janeiro: Guanabara.

(1964). Teoria política. São Paulo: W. M. Jackson.

BEVIR, Mark (2008). A lógica da história das ideias. Trad. Gilson de Sousa. Bauru (SP): Edusc.

BOBBIO, Norberto (1996). Saggi sulla scienza política in Italia. Roma: Laterza. (1997). "Ciência política" [verbete], em BOBBIO, Norberto (org). Dicionário de política, v. 1. 11. ed. Trad. Carmen Carriali et al. Brasília: Editora da UnB.

BOTELHO, André \& SCHWARCZ, Lilia Moritz (orgs.) (2009). Um enigma chamado Brasil: 29 intérpretes e um país. São Paulo: Companhia das Letras.

(2011). "Simpósio: cinco questões sobre o pensamento social brasileiro”. Lua Nova, n. 82, p. 139-59.

BRANDÃO, Gildo Marçal (1998). “A teoria política é possível?” Revista Brasileira de Ciências Sociais, v. 13, n. 36, s/p.

(2005). "Linhagens do pensamento político brasileiro". Dados, v. 48, n. 2, p. 231-69.

BRASIL, Joaquim Assis (1896). Democracia representativa: do voto e do modo de votar. 3. ed. Paris: Guillard, Aillard \& Cia.

CAMIC, Charles (1995). “Three departments in search of a discipline: localism and interdisciplinary interaction in American sociology, 1890-1940". Social Research, n. 62, p. 1003-33. 
CANDIDO, Antônio (2006). “Sociologia no Brasil”. Tempo Social, v. 18, n. 1, p. 271-301.

CARVALHO, José Murilo de (1980). "Em louvor de Victor Nunes Leal”. Dados, v. 23, n. 1, p. 5-9.

(2000). "História intelectual no Brasil: a retórica como chave de leitura”. Topoi, n. 1, p. 123-52.

(2015). "Duas ou três coisas que eu sei sobre Wanderley". Insight Inteligência, n. 71, p. 118-20.

CAVALCANTI, Temístocles Brandão (1958). Teoria do Estado. Rio de Janeiro: Borsoi.

CORBISIER, Roland (1968). Reforma ou revolução? Rio de Janeiro: Civilização Brasileira.

COSTA, João Cruz (1956). Contribuição ao estudo da história das ideias no Brasil. Rio de Janeiro: José Olympio.

CUNHA, Euclides da (1999). À margem da história. São Paulo: Martins Fontes.

DUVERGER, Maurice (1976). Ciência política: teoria e método. 2. ed. Rio de Janeiro: Zahar.

FERREIRA, Oliveiros S. (1994). "Lourival Gomes Machado". Estudos Avançados, v. 8, n. 22, p. 279-84.

FORJAZ, Maria Cecília Spina Forja (1997). "A emergência da ciência política no Brasil: aspectos institucionais". Revista Brasileira de Ciências Sociais, v. 12, n. 35, p. 101-20.

FAORO, Raimundo (1992). Existe um pensamento político brasileiro? São Paulo: Ática.

FREEDEN, Michael (2003). Ideology: a very short introduction. Oxford: Oxford University Press.

FURTADO, Celso (1965). "Obstáculos políticos ao crescimento econômico do Brasil”. Revista Civilização Brasileira, n. 1, p. 29-45.

GUNNELL, John G (1993). The descent of political theory: the genealogy of an American vocation. Chicago: University of Chicago Press.

JAGUARIBE, Hélio (1955). "O golpe de agosto". Cadernos do nosso tempo, n. 3, p. 3-20.

(1957). A filosofia no Brasil. Rio de Janeiro: Iseb.

KLOSKO, George (2011). The Oxford handbook of political philosophy. Oxford: Oxford University Press. 
LAMOUNIER, Bolívar (1977). "Formação de um pensamento político autoritário na Primeira República: uma interpretação", em FAUSTO, B. (org.). História geral da civilização brasileira, tomo III: O Brasil republicano, vol. 2. São Paulo: Difel.

(1978). "Prefácio", em SADEK, M. T. Machiavel, Machiavéis: a tragédia octaviana. São Paulo: Símbolo.

(1980). "Pensamento político, institucionalização acadêmica e relações de dependência no Brasil”. Dados, v. 23, n. 1.

(1982). "A Ciência Política no Brasil: roteiro para um balanço crítico", em IDEM (org). A ciência política nos anos 80. Brasília: Editora da UnB. LESSA, Renato (1998). "Por que rir da filosofia política?" Revista Brasileira de Ciências Sociais, v. 13, n. 36, s/p.

(2011). "Da interpretação à ciência: por uma história filosófica do conhecimento político no Brasil”. Lua Nova, n. 82, p. 17-60.

LYNCH, Christian Edward Cyril (2013a). "Por que pensamento e não teoria? A imaginação político-social brasileira e o fantasma da condição periférica (1880-1970)”. Dados, v. 56, n. 4, p. 727-67.

(2013b). "The institutionalization of Brazilian political thought in the social sciences: Wanderley Guilherme dos Santos' research revisited (1963-1978)". Brazilian Political Science Review, v.7, n. 3, p. 36-60.

(2015). "Modulando o tempo histórico: Bernardo Pereira de Vasconcelos e o conceito de 'regresso' no debate parlamentar brasileiro (1838-1840)”. Almanack, n. 10, p. 314-34.

MAGALHÃES, Domingos José Gonçalves de (1865). Obras, tomo VII: Opúsculos históricos e literários. 2. ed. Rio de Janeiro: Garnier.

MARENCO, André (2014). "The three Achilles' heels of Brazilian political science”. Brazilian Political Science Review, v. 8, n. 3, p. 3-38.

MARIÁS, Julián (2004). História da filosofia. Trad. Claudia Berliner. São Paulo: Martins Fontes.

MOREIRA, Marcelo Sevaybricker (2012). “O debate teórico-metodológico na ciência política e o pensamento social e político brasileiro". Teoria \& Pesquisa, v. 21, n. 1, p. 73-89.

NABUCO, Joaquim (1949). Balmaceda. São Paulo: Progresso Editorial.

OLIVEIRA, Lucia Lippi (1990). A questão nacional na Primeira República. São Paulo: Brasiliense. 
(1999). "Interpretações sobre o Brasil", em MICELI, Sergio (org). $O$ que ler na ciência social brasileira. Brasília: Anpocs.

PACKENHAM, Robert A. (1965). "A pesquisa política no Brasil: ponto de vista de um norte-americano". Revista de Direito Público e Ciência Política, v. 8, n. 1, p. 5-27.

PERLATTO, Fernando (2010). "Sociologia pública e o Brasil: apontamentos para um debate". Revista de Ciências Humanas, v. 1, p. 256-68.

QUIRINO, Célia (1994). "Departamento de ciência política”. Estudos avançados, v. 8, n. 22, p. 337-48.

RAMOS, Alberto Guerreiro. (1962). A crise do poder no Brasil. Rio de Janeiro: Jorge Zahar.

(1966). Administração pública e estratégia do desenvolvimento. Rio de Janeiro: Editora da FGV.

(1995). Introdução crítica à sociologia brasileira. Rio de Janeiro: Editora da UFRJ.

RICUPERO, Bernardo (2007). “A (re)conciliação com a tradição”. Revista Brasileira de Ciências Sociais, v. 22, n. 63, p. 163-5.

(2010). O conservadorismo difícil, em FERREIRA, Gabriela Nunes \& BOTELHO, André (org.). Revisão do pensamento conservador. São Paulo: Hucitec.

RODHES, R. A. W. (2008). “Old institutionalisms”, em RODHES, R. A. W.; BINDER, Sarah A. \& ROCKMAN, Bert A. The Oxford handbook of political institutions. Oxford: Oxford University Press.

ROMERO, Sílvio (1969). Obra filosófica. Introdução e seleção Luís Washington Vita. Rio de Janeiro: José Olympio.

ROSANVALLON, Pierre (2010). Por uma história do político. Introdução e trad. Christian Lynch. São Paulo: Alameda.

SADEK, Maria Tereza (1982). "Análise sobre pensamento social e político brasileiro". $B I B$, n. 12, p. 7-21.

SALES, Alberto (1882). Política Republicana. Rio de Janeiro: Leuzinger.

SANTOS, Wanderley Guilherme dos (1967). "A imaginação político-social brasileira”. Dados, n. 2-3, p. 182-93.

(1970), "Raízes da imaginação política brasileira". Dados, n. 7, p. 137-61.

(1978). Ordem burguesa e liberalismo político. São Paulo: Duas Cidades. 
(2013). “O sistema oligárquico-representativo da Primeira República". Dados, v. 56, n. 1, p. 9-37.

SOARES, Gláucio Ary Dillon (2005). "O calcanhar de Aquiles da ciência política brasileira”. Sociologia, problemas e práticas, n. 48, p. 27-52.

SOARES DE SOUSA, José Antônio (1944). A vida do Visconde de Uruguai. Rio de Janeiro: Companhia Editora Nacional.

STOPPINO, Mario (1998). "Ideologia" [verbete], em BOBBIO, Norberto (org). Dicionário de política, v. 1. 11. ed. Trad. Carmen Carriali et al. Brasília: Editora da UnB.

TORRES, Alberto (1914). A organização nacional. Rio de Janeiro: Tipografia Nacional.

VEIGA, Laura da (1992). A interação entre contexto, atividades e características organizacionais no mundo acadêmico. Análise \& conjuntura, v. 7, n. 2-3, p. 56-78.

VIANNA, Francisco José de Oliveira (1974a). Instituições políticas brasileiras. Rio de Janeiro: Record.

(1974b). Problemas de organização, problemas de direção. Rio de Janeiro: Record.

(1991). Ensaios inéditos. Campinas: Editora da Unicamp.

VILLAS-BOAS, Glaucia (1991). A tradição renovada: reflexões sobre os temas das ciências sociais no Brasil, 1945-1969, em Helena Bomeny e Patrícia Birman (org). As assim chamadas ciências sociais: formação do cientista social no Brasil. Rio de Janeiro: Relume-Dumará.

(2007). A vocação das ciências sociais no Brasil: um estudo da sua produção em livros do acervo da Biblioteca Nacional. Rio de Janeiro: FBN/MinC.

ZEA, Leopoldo (1956). Esquema para una historia de las ideas en Iberoamerica. Ciudad de México: Universidade Nacional Autónoma.

\section{Resumo}

O artigo propõe um mapa da área acadêmica de estudos do pensamento político brasileiro (PPB) no âmbito da ciência política brasileira. Na primeira seção, o trabalho explica as razões da sua indeterminação terminológica e indaga seus significados conceituais como objeto e disciplina. Como objeto, em sentido lato, o PPB alude ao conjunto de ideologias de que a cultura política do Brasil é composta, apresentadas em um estilo de escrita "periférico". De um ponto vista estrito, o PPB se refere aos "clássicos" de nossa teoria ou ciência política, 
escritos antes da institucionalização universitária na década de 1970. Na última seção, considera-se o pensamento político como disciplina universitária dedicada ao estudo da história das ideias políticas no Brasil, descrevendo-se seu desenvolvimento, suas interpretações, seus pesquisadores mais notáveis e seus principais grupos de pesquisa: o mannheimiano, o lukacsiano e o gramsciano. $O$ artigo conclui sugerindo o estreitamento das relações entre PPB e teoria política geral.

Palavras-chave: pensamento político brasileiro, pensamento social brasileiro, história das ideias políticas no Brasil, ideologias brasileiras, clássicos do pensamento brasileiro, cultura política brasileira, grupos de pesquisa do pensamento político brasileiro.

\section{Abstract}

This article intends to offer a map of the academic studies of the Brazilian political thought within the Brazilian Political Science. In the first section, the paper explains the reasons for their terminological uncertainty and asks its conceptual meanings as object and subject. As an object in the broadest sense, Brazilian political thought refers to the set of ideologies that Brazil's political culture is made, presented in a "peripheral" writing style. From a strict point of view, that expression refers to the "classics" of our theory or political science, written before the university institutionalization in the 1970s In the last section, we consider the political thought as a university discipline devoted to the study of history of political ideas in Brazil, describing their development, their interpretations, their most notable researchers and their main research groups, according to their methodological approach based on Mannheim, Lukács and Gramsci. The article concludes by suggesting a closer relationship between Brazilian political thought and general political theory.

Keywords: Brazilian political thought, Brazilian social thought, history of political ideas in Brazil, Brazilian political ideologies, Brazilian political culture, classics of Brazilian political thought, research groups in Brazilian political thought.

Recebido em 30 de setembro de 2015.

Aprovado em 4 de março de 2016. 